\title{
A ICOMI no Amapá: meio século de exploração mineral
}

Maurílio de Abreu Monteiro - Professor e pesquisador do Núcleo de Altos Estudos Amazônicos da Universidade Federal do Pará - NAEA/UFPA.

\section{Resumo}

O artigo analisa a história de meio século de exploração do minério de manganês na Serra do Navio, Amapá, Brasil, na segunda metade do século XX, pela Indústria e Comércio de Minérios S.A. (ICOMI). Aponta que houve limitada internalização do valor adicionado pela mineração. Indica que a bibliografia existente acerca das repercussões dessa atividade para o desenvolvimento regional não é satisfatória. Finaliza apontando que há uma agenda de pesquisa em aberto no que se refere à analise dos arranjos institucionais que bloquearam ou limitaram o enraizamento social do desenvolvimento na região a partir da valorização do minerio de manganês.

\section{Abstract}

This article analyzes the half-a-century history of manganese mining in Serra do Navio, Amapá, Brazil, in the second half of the twentieth century, by Indústria e Comércio de Minérios S.A. (ICOMI). It points out the fact that internalization of added value to the mining process was limited. The text also indicates that existing literature on the repercussions of this activity on regional development is insufficient. The article concludes by highlighting that an open research agenda exists regarding analysis of institutional arrangements that block or limit development of the region based on adding value to manganese mining from taking root socially.
Palavras-chave

Mineração; Amazônia; desenvolvimento regional; ICOMI; manganês.

\section{Keywords}

Mining; Amazonia; regional development; ICOMI; manganese. 


\section{INTRODUÇÃO}

A exploração do manganês da Serra do Navio, no Amapá, foi a primeira experiência de mineração industrial na Amazônia. O empreendimento foi conduzido pela Indústria e Comércio de Minérios S.A. (ICOMI), que se instalou na região na década de 50 do século XX. A atividade suscitou questionamentos acerca da sua capacidade de impulsionar processos de desenvolvimento regional, tendo sido alvo de críticas de diversas ordens.

Desde a criação do Amapá, em 1943, ainda na condição de território federal, a mineração é apontada como atividade-chave para a modernização da região (URECH, 1955; VILLELA; ALMEIDA, 1966). O primeiro mandatário do então território federal do Amapá, o interventor Janary Gentil Nunes (MORAES; MORAES, 2000), em suas declarações - diversas delas encontradas em edições do jornal O Amapá-, atribuía o desenvolvimento do território à implantação da mineração industrial na região.

Essa convicção foi expressa e sistematicamente reapresentada, ao longo do tempo, em diversas práticas governamentais, nos discursos e ações de partidos de distintos matizes políticos, nos posicionamentos e intervenções de sindicatos, tanto patronais quanto de trabalhadores. A mineração industrial, portanto, mobilizou e mobiliza uma grande pluralidade de atores sociais.

Em que pesem as expectativas, neste meio século de história da mineração industrial no Amapá, se, por um lado, as atividades minerometalúrgicas desenvolvidas na região foram competitivas e abasteceram indústrias de diversas partes do planeta, por outro, não foram capazes de impulsionar rapidamente processos regionais de desenvolvimento econômico e de modernização. Justamente por isso merece especial destaque a reflexão sobre as dinâmicas que envolveram a exploração de minérios no Amapá, pois, fechado o ciclo de exploração de diversas minas e a despeito dos resultados sociais da valorização dos recursos minerais naquele Estado, presentemente, essa atividade continua sendo apontada, por muitos, como o vetor que pode levar à modernização do Amapá e de diversas outras áreas da Amazônia Oriental brasileira, nas quais a mineração e a metalurgia são atividades que têm tido grande incremento.

\section{O MACROCENÁRIO NO QUAL SE ESTABELECEU A EXPLORAÇÃO DO MANGANÊS NO AMAPÁ}

Durante o século XX, o minério de manganês foi largamente empregado (95\%) para suprir a indústria siderúrgica, cujo valor de uso 
está estreitamente associado ao percentual de manganês contido no minério. Os minérios de manganês são classificados de acordo com o percentual do conteúdo metálico, com os componentes acessórios e ainda com sua granulometria (GONÇALVES; SERFATY, 1976, p. 7).

Assim, a mercantilização de manganês destina-se, basicamente, ao suprimento da demanda da indústria siderúrgica. Na siderurgia, de 20 a 60 kg de minério são consumidos para produzir uma tonelada de aço (GONÇALVES; SERFATY, 1976, p. 2).

O manganês também é utilizado para diminuir a quantidade de enxofre contido no ferro-gusa ou no aço. O enxofre é uma impureza constante no forno, podendo provir do próprio minério de ferro ou - o que é mais comum - resultar da utilização do coque no processo de redução (GONÇALVES; SERFATY, 1976, p. 3).

Desde o fim da Primeira Guerra, em função da crescente demanda mundial e da concentração espacial das minas, o preço do minério de manganês apresentou uma tendência altista (Gráfico 1). Com o fim da Segunda Guerra Mundial, o manganês ampliou a sua importância estratégica, pois, no âmbito da "guerra fria", a antiga União Soviética, detentora das maiores reservas mundiais de manganês, havia suspendido a sua exportação (CUNHA, 1962). No final da década de 60, o manganês atingiu o maior preço do século XX, sendo cotado, em 1957, a US\$10,21 (dólares americanos de 2003) por unidade de manganês contido no minério. Ou seja, naquele ano, a tonelada do minério de manganês com teor de $48 \%$ foi comercializada no mercado mundial, em termos médios, por US\$ 490 (valores de 2003).

Foi naquele contexto que se desenharam as condições para a valorização - entendida como a conversão em mercadoria de um recurso natural, mediante a incorporação de trabalho humano - do minério de manganês da Serra do Navio, a primeira experiência de exploração industrial de minério na Amazônia brasileira.

\section{$1.1 \mathrm{O}$ arrendamento das minas para a ICOMI}

Segundo Leal (1988), as jazidas de manganês do Amapá teriam sido descobertas no início do século XX; entretanto, essa informação teria sido mantida em sigilo até os anos 40 daquele século, para favorecer os interesses de empresas norte-americanas. Diferentemente dessa versão, que carece de base factual, diversas fontes acerca do descobrimento de jazidas de manganês no Amapá corroboram a indicação de que a descoberta teria ocorrido em 1945, em decorrência do estímulo, naquela época, à procura por minério de ferro na região, acelerada pelo fim da Segunda Guerra Mundial. 


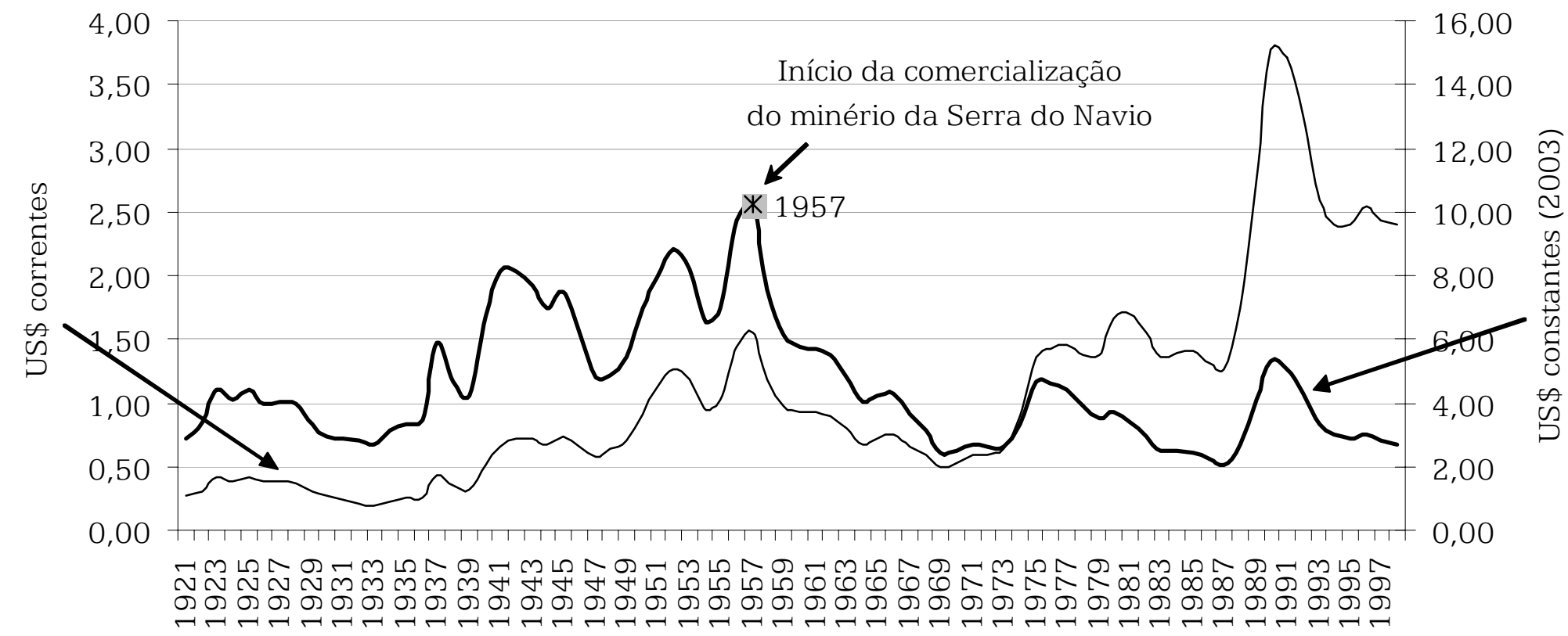

Gráfico 1: Média anual do preço do manganês no mercado mundial (1921/1998), por unidade de manganês contida no minério.

Fonte: Elaboração do autor, com base em Plunkert e Jones (1999, p. 83).

Nota: Valores convertidos em US\$ de 2003, com base nos índices disponíveis em www.bcb.gov.br. 
A versão presente em quase todas as fontes sobre o evento (por exemplo, GUERRA, 1994; URECH, 1955) ratifica a apresentada pela ICOMI, segundo a qual, em 1945, o governador do Amapá, Janary Gentil Nunes, dada a descoberta de jazidas de minério de ferro pela Hanna Mining Company, na localidade de Santa Maria do Vila Nova, passou a estimular, por meio de premiação em dinheiro, o fornecimento de indicações acerca da possível existência de outros depósitos minerais. Um dos resultados desse chamamento foi a apresentação, por um morador da região, o regatão Mário Cruz, de uma amostra de minério recolhida às margens do rio Amapari (ICOMI, 1958, p. 1).

A análise daquela amostra pelo geólogo Fritz Ackermann indicou que se tratava, não de minério de ferro, mas de minério de manganês com elevado teor (ICOMI, 1958, p. 1). Tal constatação motivou a visita de diversos geólogos ao local no qual havia sido coletada aquela porção de minério. Em tais visitas, ficou constatada a aparente relevância do jazimento. Um dos geólogos que, inicialmente, pesquisou a área de forma mais detida foi Glycon de Paiva, engenheiro do Departamento Nacional de Produção Mineral (DNPM). Dadas as evidências da grande dimensão da jazida e da conjuntura internacional, Glycon de Paiva passou a defender que a exploração da jazida só seria competitiva se houvesse uma elevada e coordenada escala de produção, o que somente poderia ser viabilizado se apenas um empreendedor efetivasse tal empreitada e se o produto tivesse como destino o mercado mundial (PAIVA; PARK JÚNIOR; DORR, 1950).

Leal (1988) afirma, com pertinência, que as teses de Glycon de Paiva foram decisivas para nortear as ações do interventor do território federal no que se refere à forma que deveria assumir a exploração das jazidas de manganês; todavia, não se pode dizer que é pertinente a indicação feita por Leal (1988) acerca da existência de vinculação das posições defendidas pelo geólogo Paiva a uma estratégia coordenada por grandes empresas norte-americanas.

Por conseguinte, o interventor do território federal, dando materialidade à tese de Glycon de Paiva, procurou montar uma estrutura institucional que permitisse que uma empresa mineradora iniciasse, o mais rápido possível, a exploração e a exportação do minério de manganês em escala capaz de atender o mercado mundial. Para tanto, conseguiu que, em setembro de 1946, por decreto-lei, o presidente da República, Eurico Gaspar Dutra, declarasse as jazidas "reserva nacional"; conseqüentemente, seu estudo e seu aproveitamento deveriam ser feitos pelo Governo do território federal do Amapá sob a orientação do Conselho Nacional de Minas e Metalurgia (CNMM) (ICOMI, 1958, p. 1).

O decreto estabelecia ainda que entidades particulares ou de economia mista poderiam ser contratadas para o aproveitamento das 
jazidas e que deveria ser garantida ao território federal do Amapá participação direta nos resultados da exploração da mina (CUNHA, 1962).

Garantida ao Amapá a coordenação do processo de exploração das jazidas de manganês, o governo do território promoveu uma espécie de concorrência para a escolha da empresa à qual seria atribuída essa tarefa. Desse certame participaram três empresas: a Hanna Coal \& Ore Corporation, a Companhia Meridional de Mineração, subsidiária brasileira da United States Steel, e a Sociedade Brasileira de Indústria e Comércio de Minérios de Ferro e Manganês (ICOMI) (AMAPÁ, 1999, p. 14). As duas primeiras eram subsidiárias das maiores empresas de mineração do mundo, a última, uma pequena empresa criada, três anos antes, pelo empresário Augusto Trajano de Azevedo Antunes para explorar minério de ferro e de manganês no Estado de Minas Gerais (FERNANDES et al., 1982, p. 524).

Inicialmente, a escolha do CNMM recaiu sobre a Hanna Coal \& Ore Corporation, todavia, a ICOMI recorreu da decisão e, em uma nova votação, realizada no CNMM, a pequena ICOMI foi escolhida. Nessa segunda votação, decidiu-se que pelo menos 51\% do capital da ICOMI deveriam ser propriedade de brasileiros natos, como já previa, inclusive, a legislação brasileira. Após a decisão do CNMM, o presidente Dutra assinou, em dezembro de 1947, o decreto que autorizou o governo territorial do Amapá a firmar contrato de prospecção com a ICOMI. Esse contrato foi assinado e registrado em cartório no Rio de Janeiro em dezembro de 1947 (CUNHA, 1962).

No ano seguinte, a ICOMI mudou sua condição jurídica, tornandose uma sociedade anônima. No início de 1949, a ICOMI comunicou ao interventor do território federal que estava em busca de um sócio estrangeiro (CUNHA, 1962). Nesse mesmo ano, sob a alegação da necessidade de aporte técnico e de recursos financeiros, a ICOMI associou-se à Bethlehem Steel Company - naquele momento, uma das gigantescas corporações norte-americanas produtoras de aço (CHANDLER, 1998, p. 127) - que passou a ter 49\% do capital da empresa. Como justificativa para a admissão do novo sócio no empreendimento, a ICOMI (1960, p. 5) argumentava:

\begin{abstract}
na ocasião, não existindo no país, nem a técnica especializada, nem os recursos financeiros, que permitissem realizar obra de mérito, à altura dos interesses da Nação, a ICOMI buscou entendimentos no exterior tendo conseguido interessar a Bethlehem Steel Company, empresa americana, que reunia todas as credenciais para tornar o empreendimento um sucesso completo.
\end{abstract}

Para alguns autores, Cunha (1962) e Leal (1988), por exemplo, aquela associação deixava evidente que a concorrência, da qual a ICOMI 
havia sido vencedora poucos anos antes, certamente envolveu acordos anteriores com a Bethlehem Steel Company, agora anunciada como sua sócia no empreendimento.

A formalização da sociedade com a empresa norte-americana requereu a revisão do contrato assinado, no final de 1947, entre a ICOMI e o governo do território do Amapá. Para tanto, foram inseridas mudanças que deram legitimidade à participação da empresa estrangeira no empreendimento. A nova versão do contrato de arrendamento foi ratificada por decreto do presidente Dutra e pelo Congresso Nacional, que a confirmou por meio de lei aprovada em novembro de 1950. Em maio do ano seguinte, o Tribunal de Contas da União também aprovou as mudanças no contrato (CUNHA, 1962).

A versão final do contrato de arrendamento das jazidas estabeleceu que a ICOMI pagaria ao governo do Amapá 4\% do valor de venda do minério e investiria 20\% dos lucros líquidos originados da exploração das minas arrendadas em novas empresas no Território.

Ainda em 1950, Augusto Trajano de Azevedo Antunes e outros empresários criaram uma nova empresa, a Companhia Auxiliar de Empresas de Mineração (CAEMI), cuja presidência coube a Trajano. A CAEMI passou a ter o seu capital integralizado por meio de ações ao portador, sem direito a voto, de ações nominativas com direito a voto na gestão da empresa. Nos anos seguintes, foi efetivada uma série de emissões e compras de ações que converteram a CAEMI na controladora da ICOMI, como uma holding. Ela detinha 51\% das ações da ICOMI, e os 49\% restantes pertenciam à Bethlehem Steel Company.

Assim, cumpria-se a legislação brasileira, em especial o Código de Minas e Águas, que exigia que, nos empreendimentos voltados para a exploração mineral, 51\% do capital estivessem sob o controle de brasileiros natos, sem se vetar, entretanto, a participação do capital estrangeiro, na condição de minoritário.

As mudanças no controle acionário da ICOMI e as alterações realizadas no contrato, inicialmente firmado em 1947, suscitaram diversas críticas sobre a legitimidade dessas modificações.

Em 1951, como determinava o contrato de arrendamento, a ICOMI entregou o relatório da pesquisa geológica iniciada em 1948. Nele se apontava a existência de reservas de 16 milhões de toneladas de minério, com teor superior a $46 \%$ de manganês. Tratava-se do resultado de uma pesquisa realizada em $65 \%$ dos 2.500 hectares concedidos para o arrendamento (ICOMI, 1958, p. 2). Tais pesquisas, mesmo que circunscritas a uma pequena parte da área a ser minerada pela empresa, indicavam a possibilidade de mercantilizar o minério ali existente. Na visão da empresa, mesmo uma estimativa conservadora permitia admitir a existência de reservas de 30 milhões de toneladas (ICOMI, 1952, p.2). 
Assim a mineradora buscou viabilizar mecanismos de financiamento do empreendimento.

\subsection{O financiamento da mineradora e as novas mudanças no contrato de arrendamento}

O Congresso Nacional, por meio da Lei n. ${ }^{0}$ 1.235, de 1950, que ratificou o contrato que autorizou a ICOMI a explorar o manganês do Amapá, também autorizou o governo federal a dar garantia do Tesouro Nacional ao empréstimo a ser contraído pela ICOMI no International Bank for Reconstruction and Development, o Banco Mundial, até o montante principal de US\$ 35 milhões de dólares (em valores de 1953, correspondentes a US\$ 241 milhões em valores de 2003) (CUNHA, 1962, p. 87).

A ICOMI, tendo formalizado a associação com a Bethlehem Steel, redimensionou para 48 milhões de dólares os valores do empréstimo necessário para financiar a implantação do empreendimento. A essa importância, foram adicionados US\$ 12 milhões (25\%) como previsão para a inflação e mais US\$ 7,5 milhões como previsão de juros correntes durante a construção, totalizando a previsão de recursos US\$ 67,5 milhões (ICOMI, 1960, p. 6). Tendo desistido da operação de crédito no Banco Mundial, a mineradora passou a pleitear, com o apoio do governo norte-americano, empréstimo no Export-Import Bank of Washington (EXIMBANK).

Como parte dessas negociações, o governo dos EUA, interessado em viabilizar o empreendimento sob sua influência, ofereceu garantias de aquisição de, no mínimo, 5,5 milhões de toneladas de minério de manganês pela Defense Material Procurement Agency, agência estatal norte-americana encarregada de manter os estoques de matérias-primas estratégicas para os EUA.

Em decorrência dessas tratativas, em 1953, com a anuência do presidente do Brasil, o EXIMBANK colocou à disposição da empresa de Trajano recursos até o limite de US\$ 67,5 milhões - em valores de 1953 -, com juros de 4,5 ao ano (ICOMI, 1960, p. 5).

Se, por um lado, o empréstimo não contou com o aval formal do Estado nacional brasileiro, sendo, tão-somente, autorizado pela Presidência da República, então ocupada por Getúlio Vargas, por outro, o credor, antes de conceder o empréstimo, exigiu, entre outras coisas, garantias de que as receitas oriundas das vendas de minério ao governo norte-americano seriam usadas para o pagamento do empréstimo e de que a empresa, durante o pagamento do empréstimo, suspenderia a aplicação no Amapá de 20\% do lucro líquido e compensaria o território do Amapá com o pagamento adicional de 1\% dos royalties.

Além de a Presidência da República, declarar, em 1953, a propósito da obtenção de financiamento para a ICOMI, que o projeto era 
"economicamente vantajoso do ponto de vista nacional" (ICOMI, 1972, p. 2), a aceitação das exigências do EXIMBANK, pelo governo federal, pelo território e pela empresa ensejou a necessidade de que, mais uma vez, fossem realizadas mudanças no contrato de arrendamento. Foi então realizado novo aditamento ao contrato. Dessa feita, ele foi justificado pelo fato de que o seu propósito era assegurar, além do empréstimo, o direito de exportar as quantidades de manganês necessárias ao pagamento integral das prestações devidas e de que esse direito importava em poder exceder ao mínimo estabelecido na cláusula 31 (500 mil toneladas anuais). Foi incluído no contrato que, caso a empresa fosse dispensada, pelo governo territorial, de fazer o investimento de $20 \%$ dos lucros, ela deveria realizar, como compensação, o pagamento de royalties adicionais equivalentes a 1\% do valor de venda do minério.

\subsection{A implementação do empreendimento}

Acertados os meios de financiamento do empreendimento, as obras de implantação da infra-estrutura necessária à valorização das reservas da Serra do Navio tiveram início em 1954. As obras civis desenvolveram-se em ritmo acelerado, foram edificados os equipamentos de infra-estrutura, que compreenderam as instalações industriais para a lavra e o beneficiamento do minério, a estrada de ferro e um embarcadouro de minério. No ano seguinte, a ICOMI iniciou a construção e a urbanização de duas vilas residenciais: Serra do Navio e Amazonas (Figura 1).

A estrada de ferro construída tem 193 quilômetros de extensão (Figura 1). Ela parte da Serra do Navio e corta uma área de floresta tropical densa. Aproximadamente sete quilômetros depois da Serra do Navio, a ferrovia transpõe o primeiro dos cinco rios que cortam seu trajeto, o Chivet. Em seguida, a pouco mais de oito quilômetros adiante, chega-se à maior ponte da ferrovia, com um vão de 220 metros, sobre o rio Amapari. A ferrovia prossegue em direção ao noroeste, ultrapassando os rios Cachorrinho e Cupixi. Depois de percorridos mais de 80 quilômetros, a paisagem deixa de ser a floresta tropical e é substituída pelo cerrado. Aproximando-se da costa, a 55 quilômetros do porto, a estrada de ferro ultrapassa o rio Frechal, para então chegar a Santana, seu destino final. Lá se localiza o embarcadouro de minérios construído pela ICOMI, a 22 quilômetros de Macapá, situado à margem esquerda do canal norte do rio Amazonas, em frente à ilha de Santana, hoje no município de Santana (Figura 1). 


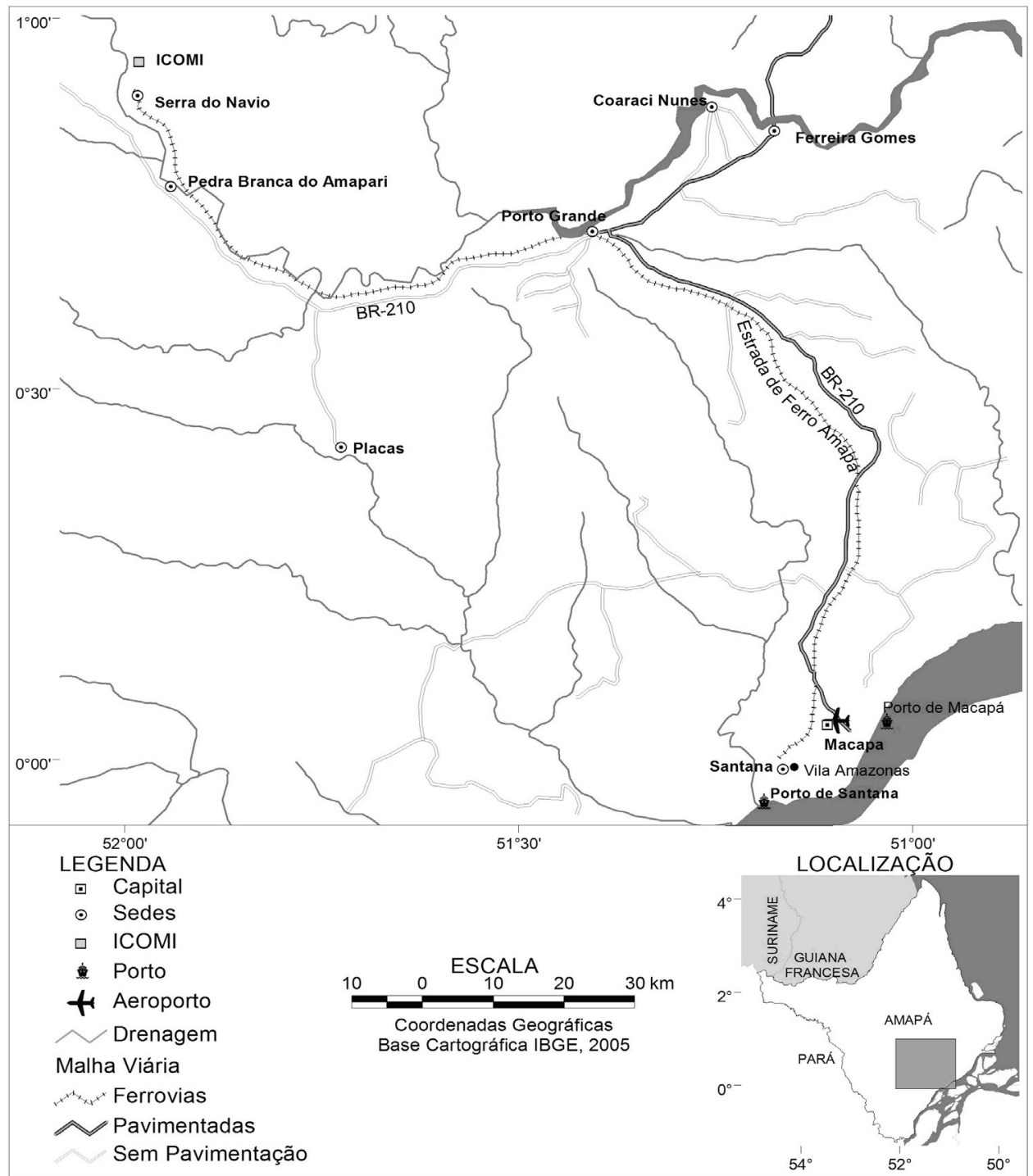

Figura 1: Localização da Serra do Navio, da Estrada de Ferro do Amapá e do porto de Santana.

Fonte: Elaboração do autor, com base em IBGE (2005).

Foram individualizadas 19 minas na Serra do Navio, agrupadas em cinco blocos distintos: Terezinha - designação emprestada da pequena vila existente à margem direita do rio Amapari, contígua à área da concessão mineral (ICOMI, 1997, p. 28) -, compreendendo as minas T-11, T-10, T-6, T-4, T-20 e T-8; Antunes - denominação que homenageou o controlador da ICOMI -, compreendendo as minas A-12 e A-3; Chumbo, compreendendo as minas C-10, C-7, C-3 C-2, C-1 e C5; Faria, compreendendo as minas F-12 e F-3; Veado, compreendendo as minas V-1, V-2 e V-4 (ICOMI, 1997, p. 26) (Figura 2). 


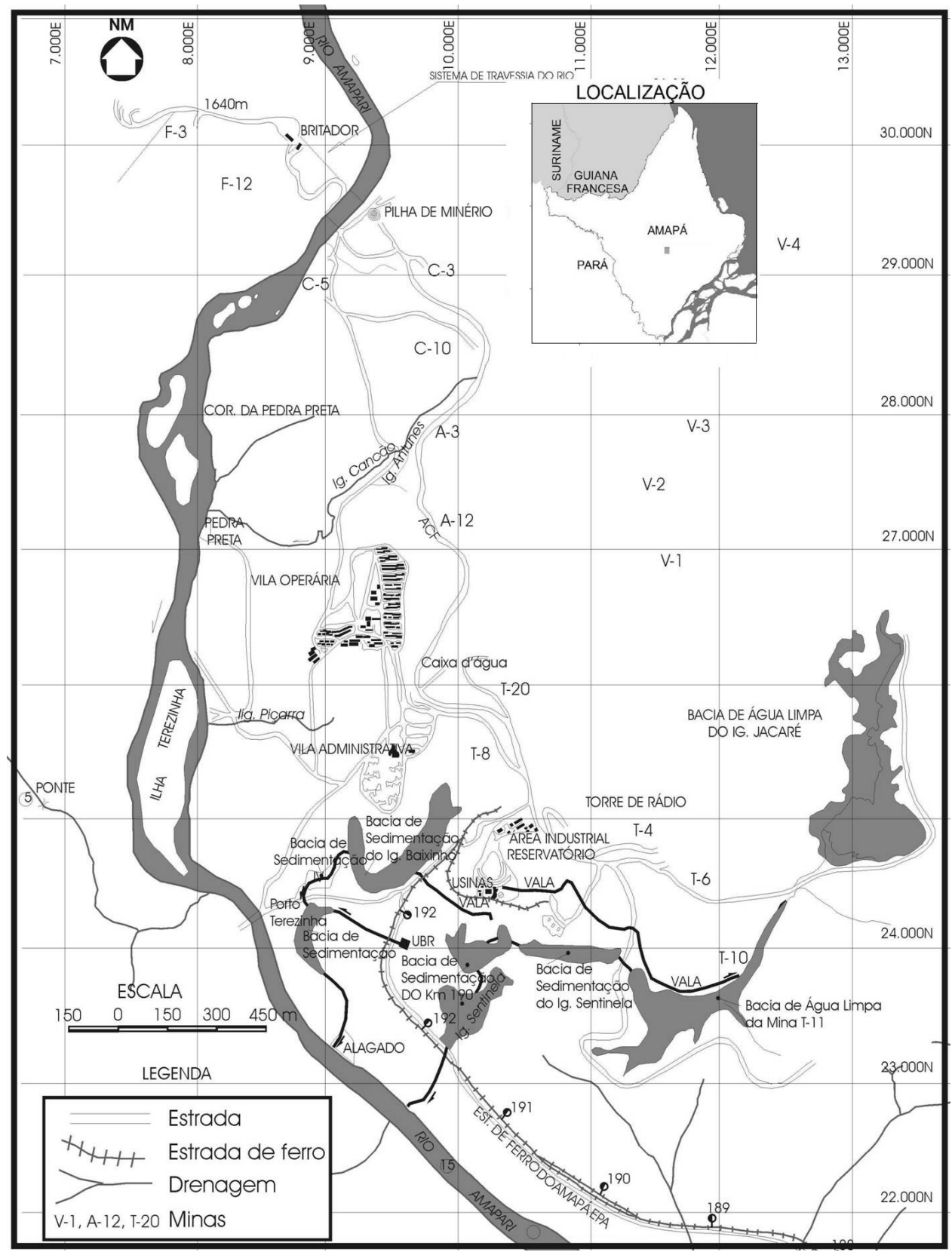

Figura 2: Mapa de localização das minas de manganês na Serra do Navio, Amapá, Brasil.

Fonte: ICOMI (1997, p. 27).

Das duas vilas residenciais construídas pela ICOMI, uma localizase às proximidades do porto de Santana e foi denominada Vila Amazonas (Figura 1). A outra, denominada Vila Serra do Navio, localiza-se perto da mina; nela foram construídas 334 casas residenciais de pelo menos quatro diferentes tipos (Tabela 1). 
Tabela 1: Relação de prédios nas vilas Serra do Navio e Amazonas, edificados pela ICOMI, Amapá.

\begin{tabular}{lr|r}
\hline \multicolumn{1}{c|}{ Tipo da construção } & $\begin{array}{c}\text { Vila } \\
\text { Serra do Navio }\end{array}$ & $\begin{array}{c}\text { Vila } \\
\text { Amazonas }\end{array}$ \\
\hline Residencial & 55 & 62 \\
Casas de pessoal administrativo & 64 & 72 \\
Casas de operários categorizados (3 quartos) & 128 & 108 \\
Casas de operários sem qualidade (3 quartos) & 88 & 72 \\
Casas de operários sem qualidade (2 quartos) & & 30 \\
Conjuntos residenciais para solteiros & 40 & 24 \\
Para pessoal administrativo (aposentados) & 48 & 72 \\
Para operários categorizados (aposentados) & 44 & 16 \\
Para operários sem qualificação (aposentados) & & \\
De uso coletivo & 18 & \\
Prédios com diversas finalidades & &
\end{tabular}

Fonte: ICOMI (1960, p. 16).

Cada modelo de casa destinava-se à moradia de um determinado segmento da hierarquia da empresa (Figura 3).

Em 30 meses, os equipamentos para a lavra, o beneficiamento e a infra-estrutura foram implantados. Para tanto foram empregados US\$ 55 milhões dos US\$ 67 milhões disponibilizados pelo EXIMBANK (ICOMI, 1972, p. 3). Estima-se que, para a implantação do empreendimento, além dos recursos provenientes do empréstimo, foi investido diretamente pela Bethelehem Steel US\$ 1,19 milhão, que se somou aos US\$ 2,13 milhões anteriormente consumidos na prospecção e no planejamento do empreendimento, totalizando, assim, US\$ 58,32 milhões, equivalentes a US\$ 398,92 milhões, em valores de 2003.

Esses investimentos permitiram que, em outubro de 1956, fosse realizado o primeiro carregamento de minério da Serra de Navio até Santana - feito festejado em uma cerimônia que contou com a presença do então presidente da República, Juscelino Kubitschek. 


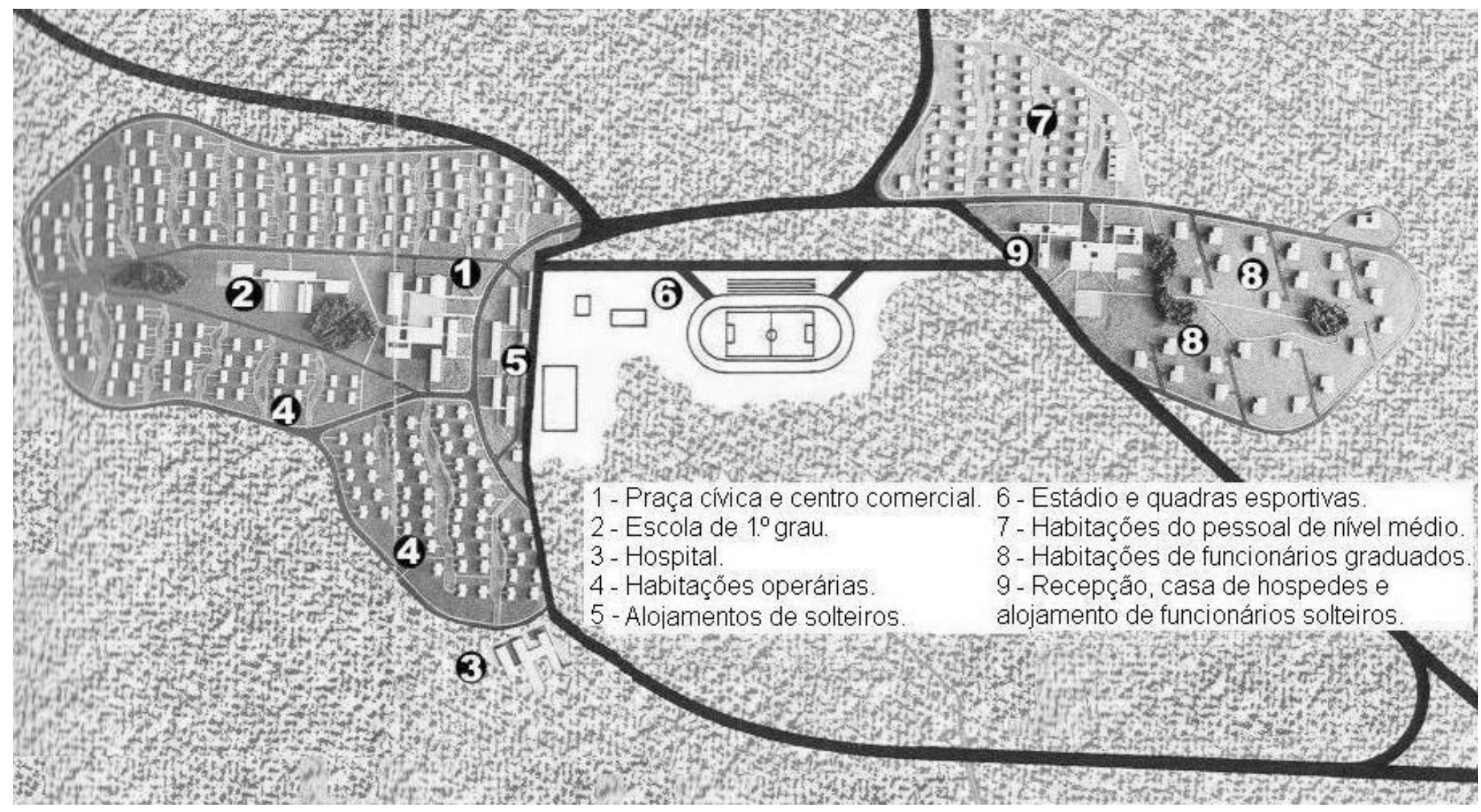

Figura 3: Planta geral da Vila Serra do Navio, Amapá. 


\section{ALGUMAS REPERCUSSÕES SOCIOECONÔMICAS DA OPERAÇÃO DA ICOMI}

A exploração do manganês da Serra do Navio provocou diversas alterações na sociedade e na economia do Amapá. Os impactos decorrentes do empreendimento tiveram sua importância ampliada pelo fato de ele ter se desenvolvido em um ambiente social caracterizado pela reduzida dimensão da economia, pelo pequeno número de habitantes e, sobretudo, pela fragilidade da organização do aparato estatal e da sociedade civil.

Verifica-se, por exemplo, que, em 1957, ano do primeiro embarque do manganês, havia apenas 419 alunos matriculados no ensino secundário (equivalente hoje ao ensino médio) no Amapá (Gráfico 2), ou seja, menos de 1/3 do número de funcionários contratados para trabalhar na ICOMI (Gráfico 3). O número total de professores do território não chegava a três centenas de funcionários. Em 1967, no décimo ano de operação da ICOMI, dos 728 professores vinculados ao governo do território do Amapá, 589 lecionavam no ensino primário, e os 139 restantes, no ensino médio. A maioria dos professores que lecionavam no ensino primário (340) nem sequer tinha concluído o ensino médio (AMAPÁ, 1968, p. 125).

Somente em 1987, o número de professores, a soldo do Estado (Gráfico 2), superou o número de empregados da ICOMI.

Por conseguinte, aquela estrutura social, demográfica, econômica e pública muito frágil foi afetada pela lavra do manganês, que suscitou diversas modificações socioeconômicas, vinculadas, especialmente, à mobilização da força de trabalho e a fluxos econômicos derivados do empreendimento.

\subsection{Mobilização e gestão da força de trabalho}

Em 1955, estima-se que a população da Vila Serra do Navio representava 4,14\% da população do Amapá (Tabela 2). Em 1959, no terceiro ano de operação industrial da ICOMI, a população da Serra do Navio já era de 2.212 habitantes (ICOMI, 1960, p. 18). A participação relativa da população da Vila Serra do Navio na população total do Amapá decaiu rapidamente nas décadas seguintes (Tabela 2 ). Todavia, não se deve menosprezar a importância que teve a atuação da ICOMI na atração populacional e, conseqüentemente, no aumento da população de outras cidades e localidades do Amapá, especialmente Macapá e Santana.

Além de influir na configuração demográfica da região, a mobilização da força de trabalho para viabilizar a mercantilização das minas de manganês do Amapá interferiu na relação entre as famílias operárias residentes nas vilas Serra do Navio e Amazonas e a direção 
da ICOMI, aparentemente, marcada por tensões. Nos relatórios da empresa, enfatiza-se que "o ajustamento social e a adaptação profissional dos empregados e seus familiares [...] apresentam alguns delicados e complexos problemas" (ICOMI, 1972, p. 29).

Tabela 2: Estimativa da evolução populacional da Vila Serra do Navio e do Amapá.

\begin{tabular}{r|r|r|r}
\hline Ano & Vila Serra do Navio & \multicolumn{1}{c|}{$\%$} & \multicolumn{1}{c}{ Amapá } \\
\hline 1943 & & $0,00 \%$ & 24.581 \\
1946 & & $0,00 \%$ & 29.098 \\
1955 & 2000 & $4,14 \%$ & 48.269 \\
1960 & 2300 & $3,34 \%$ & 68.889 \\
1970 & 3300 & $2,83 \%$ & 116.480 \\
2000 & 3300 & $0,69 \%$ & 475.843 \\
\hline
\end{tabular}

Fonte: Elaboração do autor, com base em Vergolino (2002).

Nota: Valores estimados para a Vila Serra do Navio.

A empresa atribuía os conflitos ao isolamento dos funcionários nas vilas. Para a ICOMI, a sensação de confinamento era o problema que mais interferia na "normal adaptação dos indivíduos oriundos dos grandes centros urbanos" (ICOMI, 1972, p. 29). O isolamento dos funcionários também influiria diretamente na sua postura em relação à empresa:

[desenvolviam] um tipo especial de comportamento reivindicatório e um agudo senso de elevada auto-estima; uma tendência de superestimar seu desempenho e uma alta sensibilidade em relação a qualquer ingerência na esfera dos seus interesses pessoais e seu bem-estar. A administração não pode simplesmente ignorar ou antagonizar ante esse peculiar tipo de reação cultural (ICOMI, 1972, p. 29).

Os conflitos existentes entre as famílias operárias e a mineradora, as posturas adotadas pela empresa para mediá-los e o pioneirismo da experiência na região contribuíram para que as vilas de trabalhadores edificadas e gerencaiadas pela ICOMI no Amapá fossem tomadas como referência de company town, balizando o arranjo da moradia, o modo de vida e o controle da força de trabalho em outras empresas minerometalúrgicas que se instalaram, décadas depois, na Amazônia.

Durante o funcionamento da ICOMI, a empresa teve proporcionalmente poucos funcionários terceirizados; quase todas as atividades destinadas à valorização do manganês eram realizadas por funcionários diretamente contratados pela empresa (Gráfico 3). 


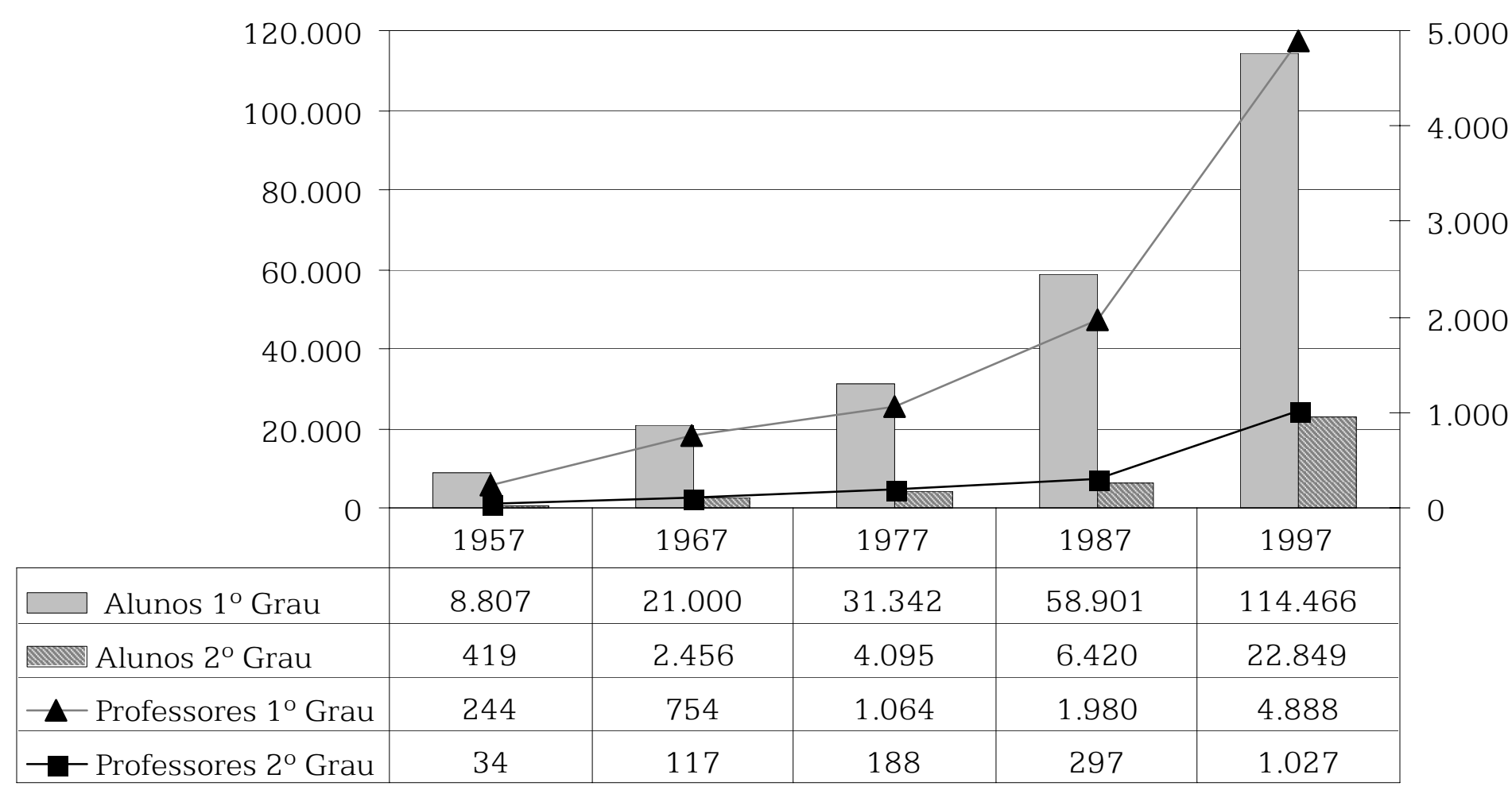

Gráfico 2: Número de alunos e professores no ensino de primeiro e segundo grau.

Fonte: Elaboração do autor, com base nos Anuários Estatísticos do Amapá (diversos anos).

Nota: A partir de 1972, houve uma mudança na organização do ensino: em lugar de um curso primário com a duração de quatro anos, seguido de um ensino secundário, compreendendo um curso ginasial de quatro séries e um curso colegial de três, passou a haver um ensino de primeiro grau com a duração de oito anos e um ensino de segundo grau, de três anos. 


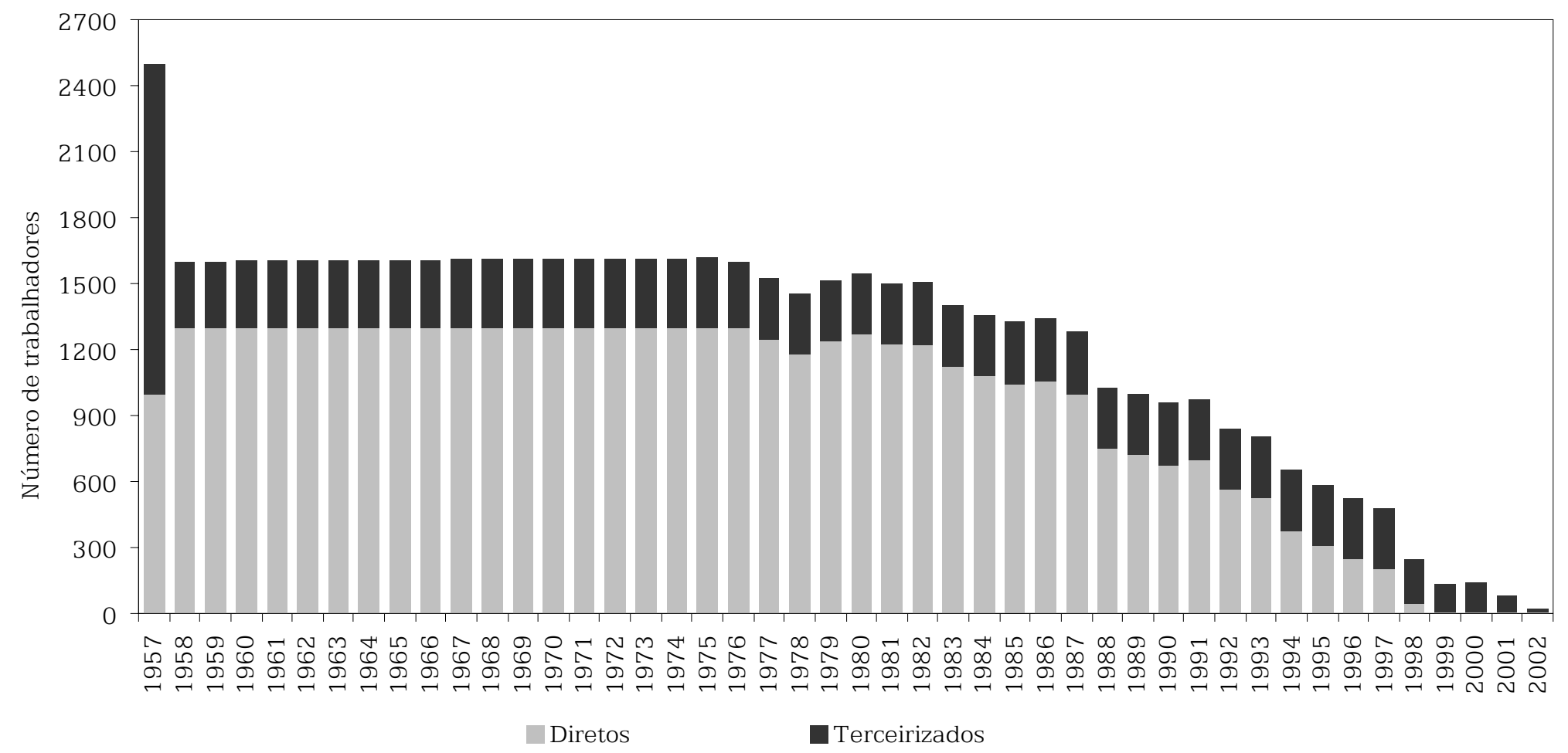

Gráfico 3: Número de trabalhadores contratados diretamente e terceirizados pela ICOMI (de 1957 a 2002). Fonte: Elaboração do autor, com base em ICOMI (1997). 
No que concerne à gestão da força de trabalho, a parcela contratada diretamente pela empresa no período de 1958 a 1986 oscilou em torno de $80 \%$ do total da força de trabalho. Eram, em média, 1290 funcionários contratados diretamente e 300 contratados por empresas terceirizadas. Esse quociente manteve-se relativamente estável até 1987, quando houve uma inflexão, e essa relação passou a regredir em função da redução continuada da força de trabalho contratada diretamente pela empresa. Essa redução prolongou-se até 2002, ano em que havia apenas quatro funcionários contratados diretamente pela empresa (Gráfico 3).

A empresa não adotou, nas últimas duas décadas do século XX, uma estratégia de terceirização agressiva, como fizeram outras empresas no mesmo período. Todavia, nos últimos anos de sua existência - a lavra foi encerrada em 1997 -, a proporção entre terceirizados e contratados diretamente aumentou porque a empresa reduziu o contingente de trabalhadores ocupados na lavra, no beneficiamento e no transporte do minério e manteve empregados de empresas terceirizados para a realização de serviços de vigilância, manutenção, entre outros (Gráfico 3).

No que se refere à produção e à produtividade física dos trabalhadores, é possível indicar pelo menos três períodos na história da empresa: o primeiro, de estabilidade em ambas, vai de 1957 a 1966; o segundo, de oscilação, vai de 1967 a 1979 - os menores valores são constatados em 1967 e 1977 e o pico, em 1971, com produtividade de 1260 toneladas por funcionário e produção de 1,6 milhão de toneladas; por fim, o terceiro período estende-se de 1980 a 1997, com tendência contínua de queda da produção e oscilação na produtividade física (Gráfico 4).

\subsection{Geração e distribuição de valor adicionado}

A mercantilização do manganês implicou a existência de um fluxo econômico oriundo, basicamente, das vendas do minério (Gráfico 5), vendas que representaram um faturamento estimado pelo autor em 4,78 bilhões (em valores de 2003). As vendas foram iniciadas em 1957, e, embora, nesse ano, tenham sido comercializadas 668 mil toneladas de minério de manganês, o faturamento da empresa foi, segundo estimativa do autor, de US\$274 milhões (Gráfico 5), o maior registrado na história da ICOMI, coincidindo também com o maior preço (em valores de 2003) do minério de manganês. 


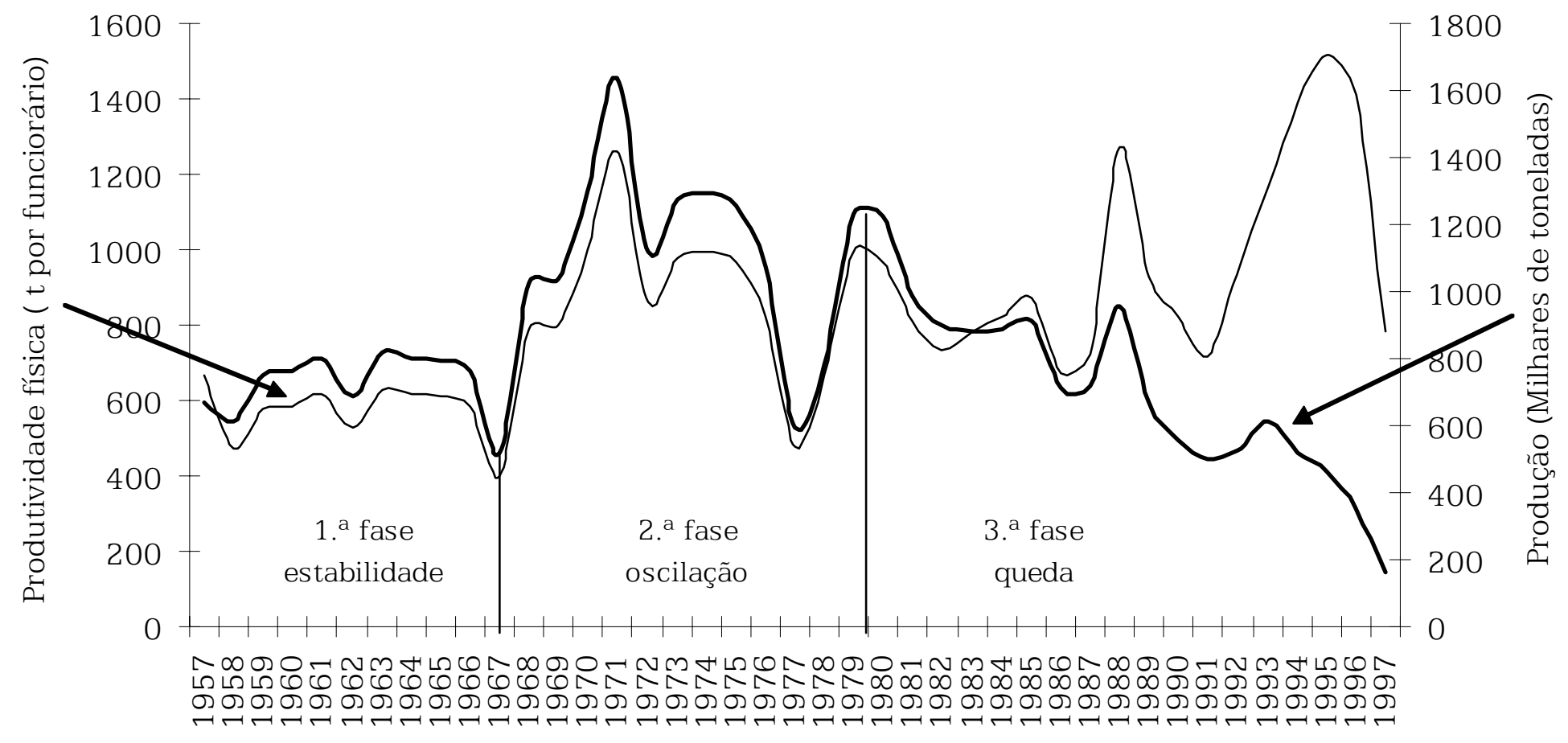

Gráfico 4: Volume da produção e da produtividade física da ICOMI (1957/1997). Fonte: Elaboração do autor, com base em ICOMI (1997) e Vergolino (2002). 
Até 1966, houve uma queda no faturamento (Gráfico 5), que se deveu basicamente à redução dos preços, uma vez que o volume de vendas permaneceu relativamente estável, em torno de 740 mil toneladas de minério por ano (Tabela 5).

No período seguinte, entre 1967 e 1979 (Gráfico 3), o volume de vendas sofreu alterações significativas (Tabela 5); em 1971, foi registrado o maior volume de vendas, 1,6 milhão de toneladas, volume que, apesar de ser 2,4 vezes maior do que o vendido em 1957, não foi capaz de superar o faturamento da empresa naquele ano.

A partir de 1980, consolidou-se uma tendência para a retração no faturamento da empresa (Gráfico 5), tendência que acompanhou, em alguma medida, a redução da produção (Gráfico 4), mas foi contrabalançada pela ligeira recuperação dos preços do minério no período (Gráfico 1).

Em termos sintéticos, é possível indicar que, durante a sua operação, a ICOMI faturou US \$ 4,78 bilhões. Desse faturamento, o autor estima que US $\$ 2,3$ bilhões foram destinados ao pagamento dos custos operacionais. Assim, grosso modo, pode-se inferir que o valor adicionado pelas operações da ICOMI foi de 2,5 bilhões - valor adicionado que, em termos estimativos, foi distribuído como apresentado no Gráfico 6.

\subsubsection{Remuneração da força de trabalho}

Quanto ao valor adicionado pela mercantilização do manganês, segundo estimativa do autor, da parcela destinada à remuneração da força de trabalho, resultou, entre 1957 e 1980, uma remuneração média anual paga a cada um dos empregados de US\$ 6,9 mil (Tabela 3). Tratase de remuneração muito superior à média existente no Amapá. Essa remuneração ensejava, por via de conseqüência, a injeção anual de pelo menos US\$ 8,4 milhões na economia. 


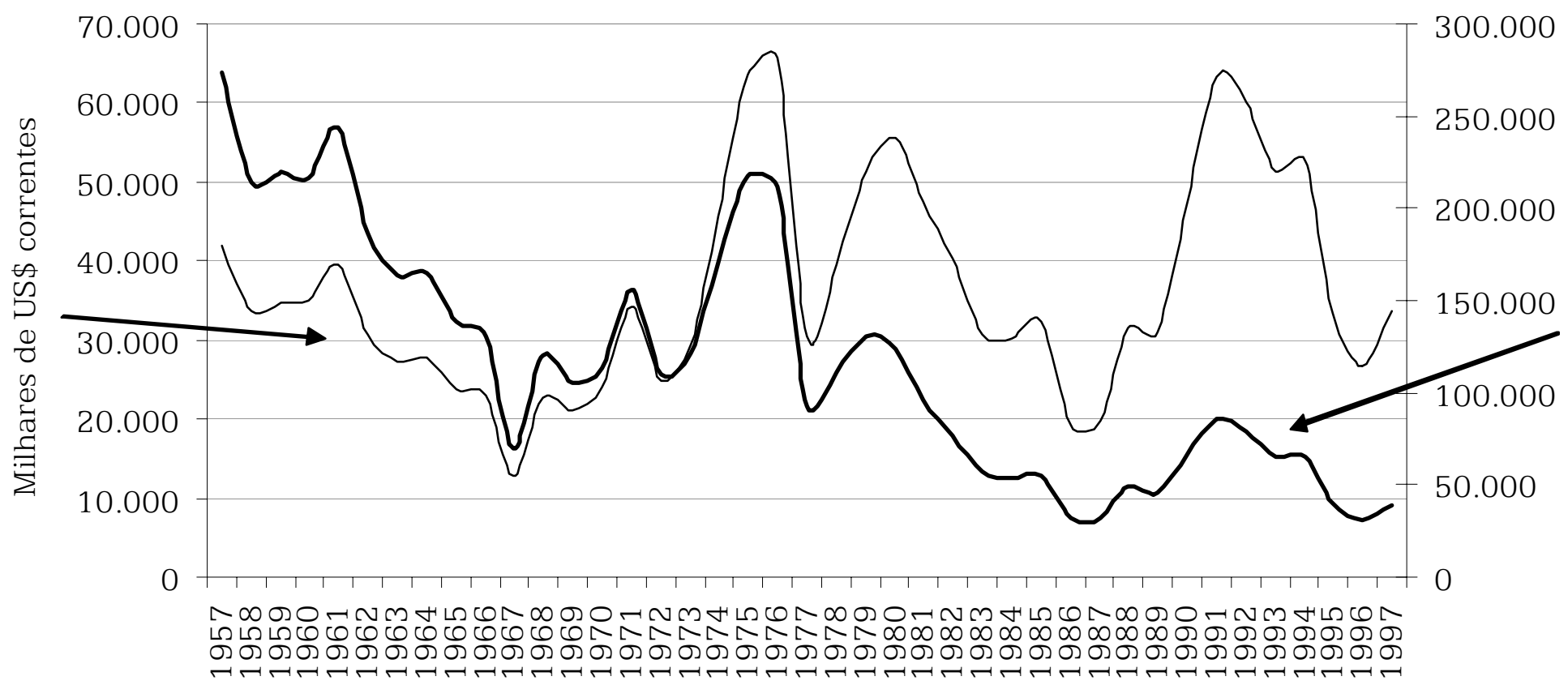

Gráfico 5: Estimativa dos valores das vendas da ICOMI (1957/1997).

Fonte: Elaboração do autor, com base em Vergolino (2002) e ICOMI (1997).

Notas:1 Estimativa elaborada considerando valores de royalties pagos com alíquotas de 5\% entre 1957 e 1963 e de $4 \%$ entre 1964 e 1997. 2 Valores convertidos em US\$ de 2003, com base nos índices disponíveis em www.bcb.gov.br. 


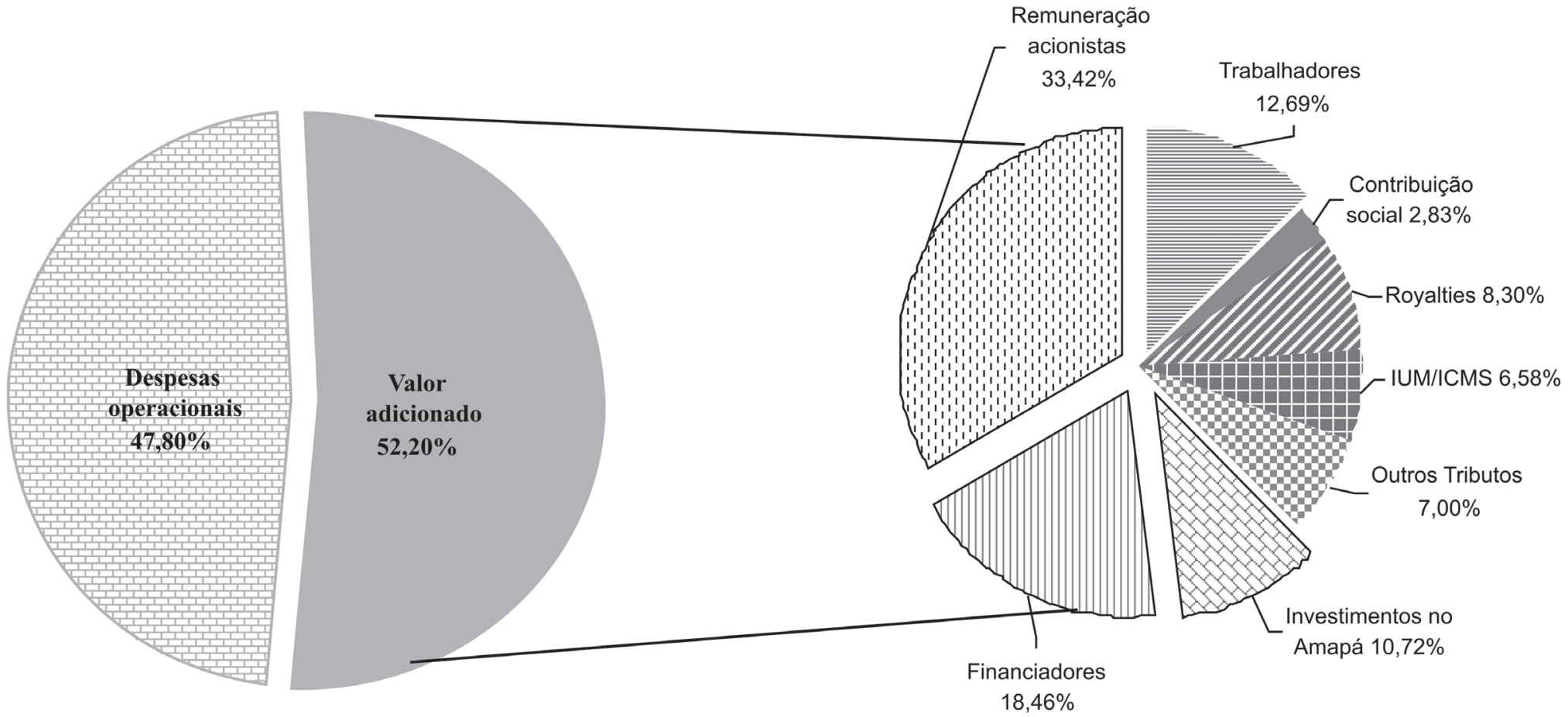

Gráfico 6: Estimativa da geração e da distribuição de valor adicionado pela ICOMI (1957/1997). Fonte: Elaboração do autor, com base em Vergolino (2002) e ICOMI (1997). 
No período de 1980 a 1997, houve uma redução constante no número de funcionários (Gráfico 3) e, também, uma redução no total dos proventos pagos pela empresa (Tabela 3). Nesse período, em termos médios, as remunerações pagas aos empregados implicaram a disponibilização anual de US\$ 6 milhões para a economia amapaense (Gráfico 4). Por conseguinte, é possível inferir que, em meio século de operação da ICOMI, houve o pagamento total de proventos da ordem de US\$ 316,5 milhões (Tabela 3), que representaram 13\% do valor adicionado gerado pela valorização do minério de manganês (Gráfico 6).

Tabela 3: Valores dos proventos pagos com encargos pela ICOMI (1957/ 2001).

US\$ 1,00 (2003).

\begin{tabular}{|c|c|c|c|c|c|c|}
\hline Anos & Empregados & $\begin{array}{c}\text { Média anual de } \\
\text { remuneração } \\
\text { por empregado }\end{array}$ & $\begin{array}{c}\text { Total de } \\
\text { proventos } \\
\text { pagos no } \\
\text { período }\end{array}$ & \begin{tabular}{|c|} 
Total de \\
encargos \\
(1) diretos \\
no período
\end{tabular} & \begin{tabular}{|c|} 
Total de \\
encargos (2) \\
opcionais \\
no período \\
\end{tabular} & Total \\
\hline 1957/1966 (3) & 1280 & 6.998 & 89.578 .817 & 18.877 .733 & 2.562 .413 & 111.018 .963 \\
\hline 1967/1979 (3) & 1270 & 6.998 & 115.542 .678 & 14.521 .333 & 1.971 .087 & 132.035 .098 \\
\hline 1980/1990 (3) & 1010 & 6.998 & 77.751 .614 & 17.161 .575 & 2.329.466 & 97.242 .656 \\
\hline 1991 & 697 & 7.028 & 4.898 .842 & 1.605 .884 & 387.518 & 6.892 .244 \\
\hline 1992 & 560 & 9.790 & 5.482 .152 & 1.887 .265 & 442.947 & 7.812 .364 \\
\hline 1993 & 526 & 10.065 & 5.294 .082 & 1.832 .071 & 579.748 & 7.705 .901 \\
\hline 1994 & 375 & 13.645 & 5.116 .947 & 1.591 .294 & 554.753 & 7.262 .994 \\
\hline 1995 & 306 & 11.460 & 3.506 .721 & 1.040 .181 & 353.616 & 4.900 .518 \\
\hline 1996 & 248 & 13.251 & 3.286 .189 & 862.239 & 299.066 & 4.447 .494 \\
\hline 1997 & 203 & 12.223 & 2.481 .188 & 732.386 & 221.122 & 3.434 .696 \\
\hline 1998 & 47 & 52.109 & 2.449 .119 & 493.579 & 64.938 & 3.007 .635 \\
\hline 1999 & 6 & 146.735 & 880.407 & 69.008 & 10.893 & 960.307 \\
\hline 2000 & 5 & 25.382 & 126.909 & 32.231 & 4.947 & 164.087 \\
\hline 2001 & 4 & 29.560 & 118.238 & 36.477 & 4.079 & 158.795 \\
\hline Total geral & & & 316.513 .904 & 60.743 .256 & 9.786 .592 & 387.043 .752 \\
\hline
\end{tabular}

Fonte: Estimativas do autor, com base em Vergolino (2002).

Notas: (1) encargos sociais, (2) previdência privada e seguro de vida, (3) estimado. Valores convertidos em US\$ de 2003, com base nos índices disponíveis em www.bcb.gov.br.

\subsubsection{Reinvestimentos no Amapá}

Além dos laços estabelecidos com a socioeconomia da região, por causa da destinação do valor adicionado decorrente da valorização do minério de manganês para remunerar a força de trabalho, a ICOMI estabeleceu outros vínculos. Um desses vínculos decorre da obrigação contratual de efetivar novos investimentos na região. Assim, uma parte do valor adicionado que coube aos donos do empreendimento foi reinvestida no Estado, pois o contrato relativo à exploração do manganês da Serra do Navio estipulava que, além do pagamento de royalties, a empresa deveria reinvestir 20\% dos seus lucros líquidos na região.

Para dar por cumprida essa exigência, a ICOMI incluía, como investimentos de lucros no Estado do Amapá, projetos direcionados a atividades estritamente ligadas às inversões que ela necessitou realizar em função das exigências do mercado mundial de manganês. Foi o 
caso da construção da usina de pelotização e da usina de sinterização do minério (Tabela 4). Esses investimentos foram apresentados à sociedade pela empresa como "reinvestimentos" no Estado de lucros auferidos com a exploração do minério de manganês.

Além dessas inversões diretamente ligadas à valorização do minério de manganês da Serra do Navio, a ICOMI também criou a Companhia Ferro-Ligas do Amapá (CFA), a Bruynzeel Madeira S.A. (BRUMASA) dedicada à produção de madeira compensada -, a Amapá Florestal e Celulose S.A. (AMCEL) - detentora de um projeto florestal que envolve 172 mil ha, voltado para o plantio, em áreas do cerrado amapaense, de pínus tropicais e para a produção de cavacos de madeira exportados para indústrias de celulose - e a Companhia de Dendê do Amapá (CODEPA) uma agroindústria com atividade dirigida para o plantio de dendê.

Tabela 4: Reinvestimento realizados, no Amapá, pelos controladores da ICOMI. 1000 (US\$2003).

\begin{tabular}{lr}
\hline \multicolumn{2}{c}{ Investimentos } \\
\hline Pelotização & 37.393 \\
Indústria açucareira & 4.282 \\
Instituto Regional de Desenvolvimento do Amapá & 1.002 \\
Bruynzeel Madeira S.A. & 42.846 \\
Amapá Florestal e Celulose & 48.106 \\
Companhia Dendê do Amapá & 13.460 \\
Companhia Progresso do Amapá & 4.347 \\
Companhia Ferro-Ligas do Amapá & 31.158 \\
Outros investimentos & 84.809 \\
Total & 267.403 \\
\hline
\end{tabular}

Fonte: Elaboração do autor, com base em ICOMI (1997, p. 106).

O autor estima que, dos US $\$ 2,5$ bilhões relativo ao valor adicionado que foram apropriados pelos capitalistas, US\$267,4 milhões (10,7\%) foram reinvestidos no Amapá (Tabela 4).

Evidenciou-se, portanto, baixa capacidade (10,7\%) de internalizar, em âmbito regional, uma parte significativa do valor adicionado decorrente da valorização do manganês.

\subsubsection{Pagamento de royalties e de impostos}

Outro impacto socioeconômico da mercantilização das minas de manganês da Serra do Navio foi representado pelos royalties e pelos impostos resultantes da atividade. Como já se indicou, os royalties incidentes sobre as vendas da mineradora foram de 5\% entre 1957 e meados de 1967 e de 4\%, entre 1968 e 1977 . Naquele primeiro período, houve queda no valor dos royalties arrecadados (Gráfico 7). Esse comportamento não se deveu à redução da produção, que se manteve relativamente estável no período (Tabela 5); tal queda foi derivada, sobretudo, da retração constante dos preços do minério de manganês no mercado mundial (Gráfico 1). 


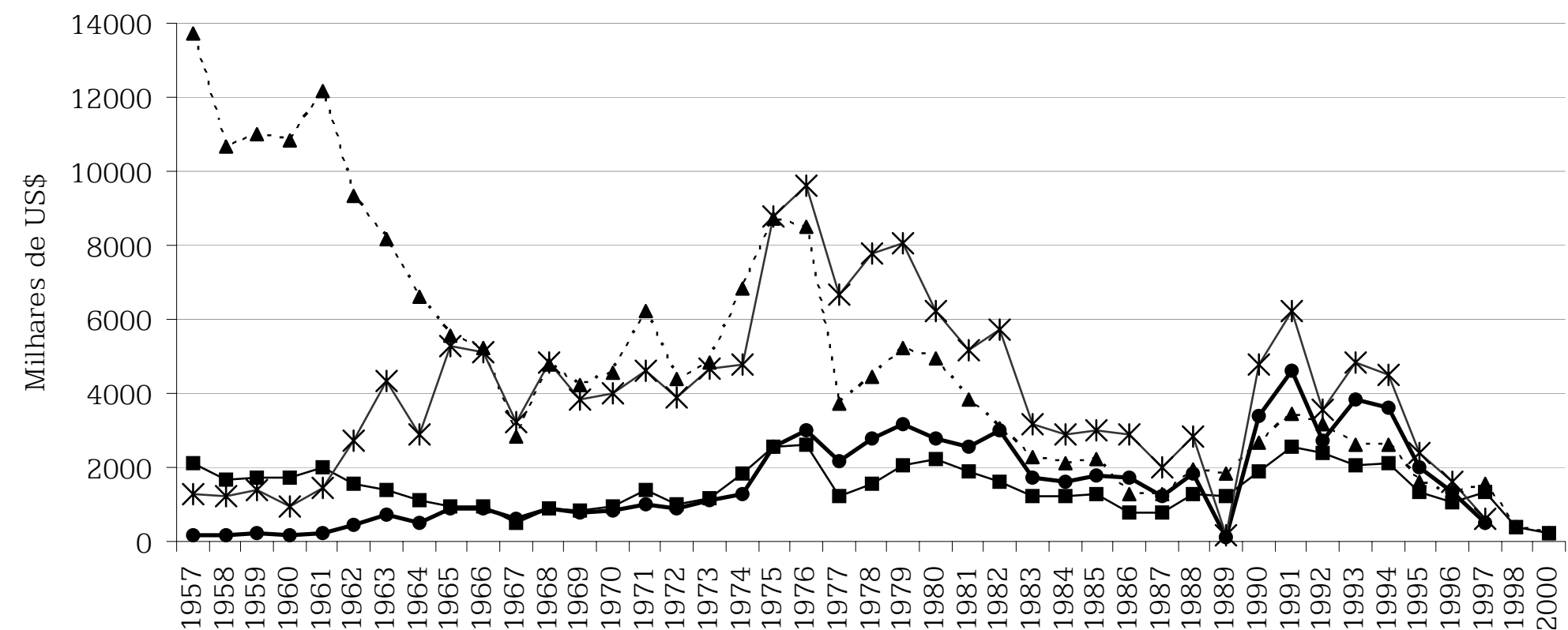

$\longrightarrow$ Royalties Correntes …- Royalties Constantes $\longrightarrow$ IUM/ICMS Correntes $\longrightarrow$ IUM/ICMS Constantes

Gráfico 7: Valores dos royalties e do IUM/ICMS pagos pela ICOMI (1957/2000).

Fonte: Elaboração do autor, com base em Vergolino (2002) e ICOMI (1997).

Nota: Valores convertidos em US\$ de 2003, com base nos índices disponíveis em www.bcb.gov.br. 
Até 1980, a totalidade dos royalties derivados da valorização do manganês da Serra do Navio, por força de legislação específica (Lei n. ${ }^{\circ}$ 2.740, de março de 1956), foi transferida pelo governo do Amapá à Companhia de Eletricidade do Amapá, uma empresa pública criada com a responsabilidade de dinamizar os sistemas de produção, transmissão e distribuição de energia elétrica no então território federal do Amapá. A principal aplicação do recurso foi feita na construção da hidrelétrica do Paredão, cujo fornecimento de energia elétrica permitiu a futura operação de projetos do próprio grupo da ICOMI, como a Companhia Ferro-Ligas do Amapá (CFA).

Apesar da existência de uma tendência para a queda de preço do manganês, é possível inferir que, em termos médios, a arrecadação de royalties e do Imposto Único sobre Minerais (IUM), posteriormente abarcado pelo Imposto sobre Circulação de Mercadorias e Serviços (ICMS), representou, durante os 40 anos de operação, ingressos anuais nos cofres públicos do Amapá de valores equivalentes, respectivamente, a US\$ 5 milhões e a US\$ 4 milhões, corrigidos para 2003.

A título de comparação, pode-se indicar que, em 1976, a arrecadação de impostos federais no Amapá foi de US\$ 8,13 milhões (em valores de 2003) (Amapá, 1977, p. 151); já os royalties, que, em sentido estrito, não podem ser considerados um imposto, representaram US\$ 6,6 milhões, pagos pela ICOMI (Gráfico 7).

Do valor adicionado gerado pela valorização do minério de manganês na história da ICOMI, US\$ 207 milhões destinaram-se ao pagamento de royalties e US\$ 164 milhões, ao pagamento do IUM e posteriormente do ICMS. Esses valores representam 9,06\% e 7,18\% do valor adicionado total. São percentuais mais elevados do que os que presentemente incidem sobre qualquer atividade de extração industrial de minerais em curso na Amazônia brasileira.

A redução das alíquotas dos royalties e a diminuição da incidência de impostos devem-se a alterações processadas na legislação, como a extinção do Imposto Único sobre a Mineração (IUM) e o estabelecimento da Contribuição Financeira sobre Exploração Mineral (CFEM). Tais mudanças estabeleceram parâmetros que limitaram as alíquotas de royalties a percentuais não superiores a 3\% sobre o valor líquido das vendas do bem mineral. A isso se somou a "desoneração" tributária referente à mercantilização de bens semi-elaborados destinados à exportação, incluindo os minerais.

Trata-se, portanto, de uma constatação relevante, quando se pretende verificar o potencial da mineração industrial nos processos de modernização da Amazônia brasileira, pois, presentemente, no âmbito dos marcos regulatórios vigentes, os linkages fiscais decorrentes da exploração industrial de minerais na Amazônia brasileira são 
significativamente menores do que os que existiram nas quatro décadas de valorização do manganês da Serra do Navio.

\section{A ESPECIFICIDADE DO MERCADO MUNDIAL DE MANGANÊS E SUAS REPERCUSSÕES LOCAIS}

As especificidades naturais de cada minério influenciam significativamente a estruturação dos mecanismos de sua extração, bem como a organização das etapas seguintes de sua valorização. Todavia, a mercantilização de qualquer minério, como o de manganês, tem seus fundamentos produtivos vinculados, em última instância, às determinações gerais que condicionam a elaboração de qualquer mercadoria. Assim, as restrições como localização, topografia, configuração geológica da jazida ou mesmo as propriedades físicoquímicas do minério que lhe conferem valor de uso ajudam a fornecer, tão-somente, algumas indicações sobre as lógicas com base nas quais são edificadas estruturas que permitem a mercantilização do minério.

Por isso, a localização planetária das reservas de manganês - a concentração de jazidas em territórios de alguns estados nacionais e a não existência de grandes depósitos nos territórios dos maiores consumidores - influenciou a estruturação da exploração mundial do minério de manganês. Todavia, os fundamentos explicativos do comportamento dos diversos agentes sociais envolvidos na mercantilização desse recurso natural residem em dinâmicas econômicas e políticas.

No início da década de 50, a URSS e a Índia eram responsáveis sozinhas pela mercantilização de mais de 60\% do minério de manganês do planeta (Gráfico 8). Mas, durante essa década, houve mudanças significativas no mercado do minério de manganês, em especial em decorrência do início da exploração de minas no Gabão, na Austrália e da própria mina da Serra do Navio.

Assim, com o início das atividades da ICOMI, o Brasil tornou-se o quarto maior produtor de minério de manganês, passando a mercantilizar pouco mais de 1 milhão de toneladas, a maior parte extraída da Serra do Navio. Essa produção só era superada pela da então União Soviética, pela da África do Sul e pela da Índia (Gráfico 8). 


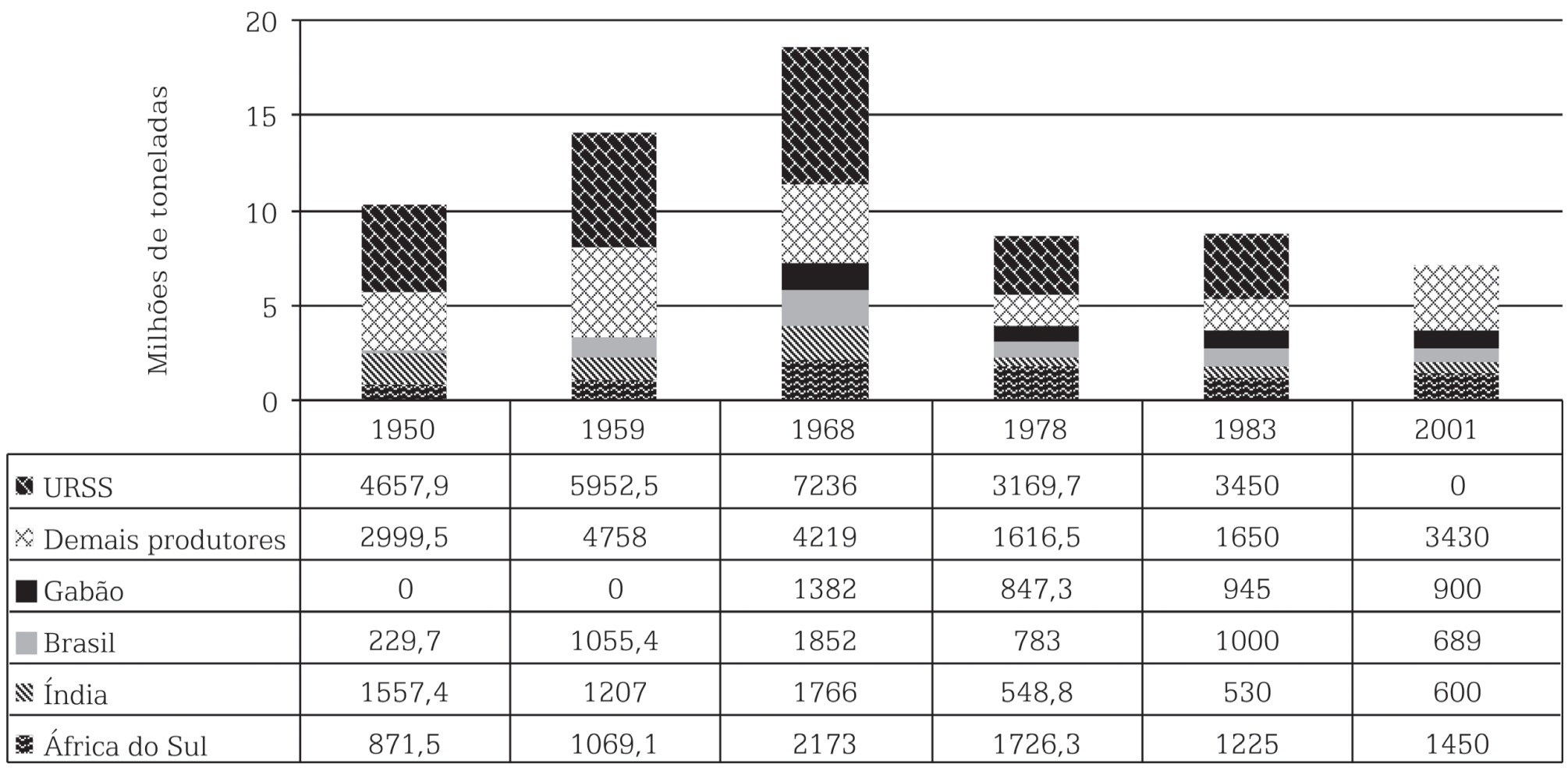

Gráfico 8: Volume e principais produtores de minério de manganês no mundo (1950/2001). Fonte: Elaboração do autor, com base em PLUNKERT e JONES (1999) e DNPM (2002). 
Entre 1957 e 1962, dos 4,3 milhões de toneladas de minério de manganês extraídas da Serra de Navio, a quase totalidade $(99,24 \%)$ foi destinada aos Estados Unidos (Gráfico 9). A destinação do minério para os EUA, nos seis primeiros anos de operação da ICOMI, vincula-se ao cumprimento dos acordos que levaram à obtenção do empréstimo para financiar o empreendimento. Isso se materializou mediante as compras efetuadas pelo governo dos EUA, para fins de estocagem. Outro elemento que justifica o perfil das vendas da ICOMI são as compras efetuadas pela própria Bethlehem Steel.

Nos primeiros anos de operação da ICOMI, os preços do minério estavam altos, mas já iniciavam a sua trajetória de queda (Gráfico 1). Naqueles seis anos, foi pago o empréstimo que financiou o empreendimento. O pagamento, nesse prazo, foi favorecido pelo fato de que, naquele período, 20\% dos lucros líquidos não foram reinvestidos no Amapá, tendo tais recursos sido canalizados para o pagamento do EXIMBANK. E, como previa o contrato de arrendamento, a ICOMI efetuou o pagamento adicional de $1 \%$ de royalties.

No decorrer dos anos 60, houve mais alterações no mercado mundial de manganês, com destaque para a entrada em operação da mina Comilog, no Gabão, cuja produção anual era superior a 1,3 milhão de toneladas (ICOMI, 1972, p. 26). Essa mina pertencia ao Grupo da U.S. Steel, a maior produtora de aço do mundo, que pode colocar uma quantidade enorme de manganês no mercado internacional (REIS, 1968, p. 7). Tal situação permitiu à U.S. Steel, outrora cliente da ICOMI, suprir suas próprias necessidades e, concomitantemente, exercer uma política de venda bastante agressiva nos mercados europeus (REIS, 1968, p. 8). O aumento do volume do minério de manganês disponível no mercado global resultou em uma reversão na tendência de elevação de preços existente desde a década de 20, passando a haver, a partir dos anos 60, uma tendência de queda do preço do minério (Gráfico 1).

Assim, concomitantemente ao término do pagamento do empréstimo, foram consolidadas importantes transformações no mercado global do minério de manganês, com efeitos na produção local e na sua destinação. Dessa conjunção de fatores resultou, entre 1964 e 1969, uma drástica redução na proporção entre o minério extraído na Serra do Navio e a fração destinada a abastecer os EUA (Gráfico 9). 


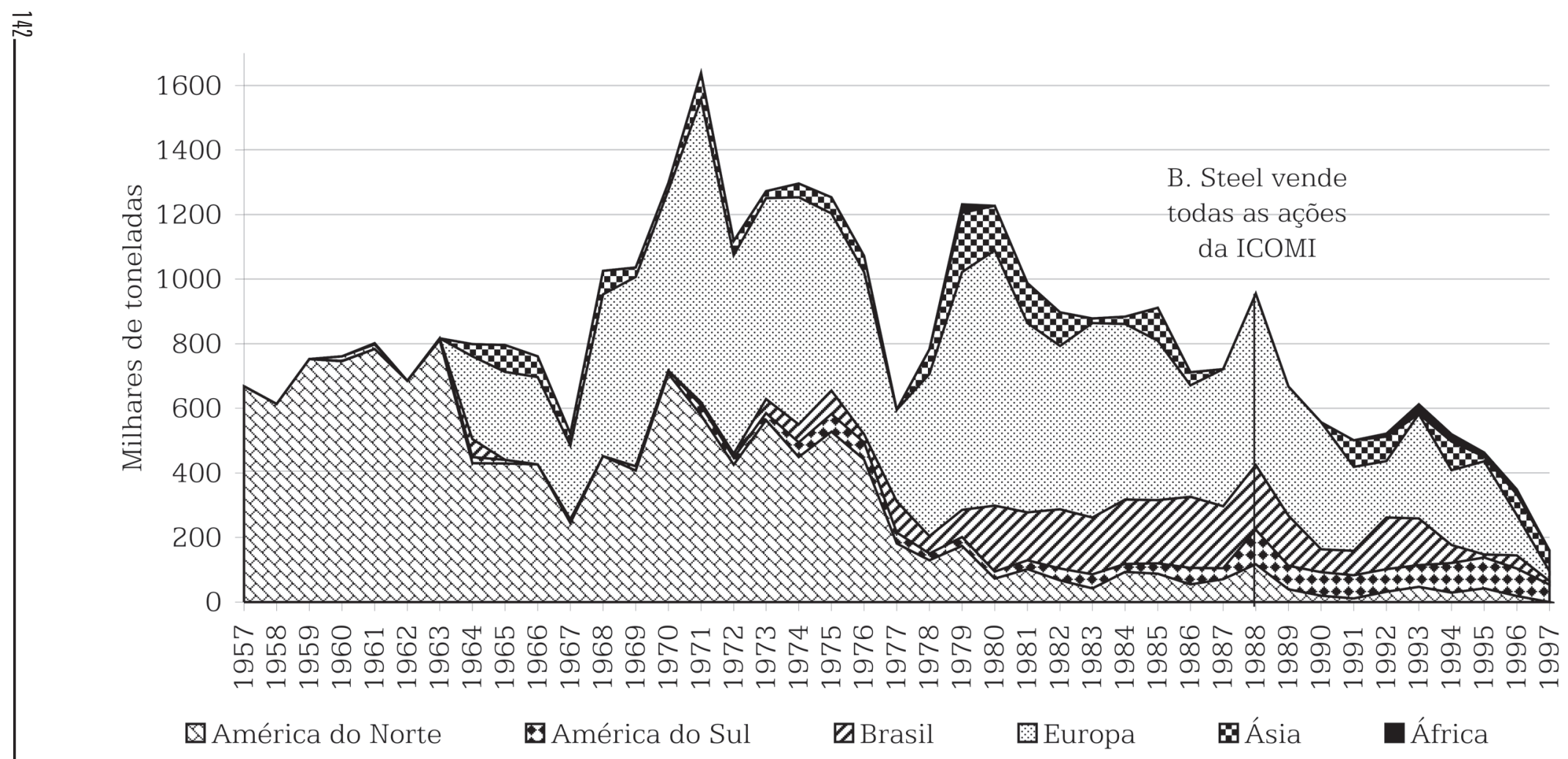

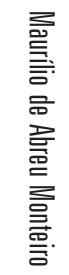

Gráfico 9: Indicação da destinação do minério manganês valorizado a partir da exploração das minas da Serra do Navio.

Fonte: Elaboração do autor, com base em ICOMI (1997, p. 105). 
Tabela 5: Destinação do minério de manganês extraído das minas da Serra do Navio, Amapá (em toneladas).

\begin{tabular}{|c|c|c|c|c|c|c|c|}
\hline Ano & $\begin{array}{c}\text { América do } \\
\text { Norte }\end{array}$ & $\begin{array}{c}\text { América do } \\
\text { Sul }\end{array}$ & Brasil & Europa & Ásia & África & Total \\
\hline 1957 & 668.275 & & & & & & 668.275 \\
\hline 1958 & 614.096 & & & & & & 614.096 \\
\hline 1959 & 752.811 & & 130 & & & & 752.941 \\
\hline 1960 & 746.327 & & 257 & 14.071 & & & 760.655 \\
\hline 1961 & 783.773 & & 420 & 14.030 & 3.361 & & 801.584 \\
\hline 1962 & 685.531 & & 302 & & & & 685.833 \\
\hline 1963 & 811.127 & 5.226 & 99 & & & & 816.452 \\
\hline 1964 & 430.052 & 19.348 & 55.701 & 256.104 & 37.695 & & 798.900 \\
\hline 1965 & 429.344 & 11.137 & 50 & 272.811 & 82.795 & & 796.137 \\
\hline 1966 & 426.231 & & & 270.195 & 64.748 & & 761.174 \\
\hline 1967 & 244.533 & 11.898 & & 228.586 & 36.644 & & 521.661 \\
\hline 1968 & 451.752 & & 3 & 500.925 & 72.807 & & 1.025 .487 \\
\hline 1969 & 407.605 & 12.716 & & 587.049 & 29.362 & & 1.036 .732 \\
\hline 1970 & 707.111 & 9.839 & & 558.844 & 22.350 & & 1.298 .144 \\
\hline 1971 & 578.744 & 30.041 & 10.855 & 936.294 & 82.562 & & 1.638 .496 \\
\hline 1972 & 425.449 & 22.075 & 11.705 & 614.662 & 44.741 & & 1.118 .632 \\
\hline 1973 & 563.985 & 20.862 & 43.971 & 622.088 & 22.153 & & 1.273 .059 \\
\hline 1974 & 449.034 & 45.821 & 55.300 & 703.152 & 42.669 & & 1.295 .976 \\
\hline 1975 & 527.177 & 55.489 & 72.969 & 548.086 & 50.336 & & 1.254 .057 \\
\hline 1976 & 441.781 & 52.795 & 25.118 & 502.631 & 50.035 & & 1.072 .360 \\
\hline 1977 & 181.615 & 33.671 & 96.676 & 284.004 & & & 595.966 \\
\hline 1978 & 129.562 & 20.904 & 53.570 & 502.054 & 76.998 & & 783.088 \\
\hline 1979 & 174.098 & 27.272 & 84.238 & 736.447 & 183.100 & 26.596 & 1.231 .751 \\
\hline 1980 & 73.106 & 21.584 & 204.151 & 790.054 & 137.959 & & 1.226 .854 \\
\hline 1981 & 102.431 & 26.906 & 148.673 & 586.174 & 123.411 & & 987.595 \\
\hline 1982 & 67.413 & 36.775 & 183.508 & 505.306 & 104.397 & & 897.399 \\
\hline 1983 & 42.324 & 43.500 & 176.536 & 601.765 & 14.498 & & 878.623 \\
\hline 1984 & 93.594 & 24.496 & 199.598 & 544.032 & 22.700 & & 884.420 \\
\hline 1985 & 87.478 & 32.995 & 195.094 & 494.221 & 101.327 & & 911.115 \\
\hline 1986 & 54.702 & 50.882 & 220.219 & 345.919 & 40.179 & & 711.901 \\
\hline 1987 & 70.774 & 34.064 & 192.291 & 424.070 & & & 721.199 \\
\hline 1988 & 117.376 & 107.150 & 200.428 & 529.637 & & & 954.591 \\
\hline 1989 & 39.670 & 72.505 & 155.384 & 399.896 & & & 667.455 \\
\hline 1990 & 19.914 & 73.082 & 70.630 & 392.940 & & & 556.566 \\
\hline 1991 & 11.391 & 71.688 & 75.795 & 259.537 & 82.958 & & 501.369 \\
\hline 1992 & 32.185 & 69.961 & 160.090 & 174.586 & 75.279 & 9.999 & 522.100 \\
\hline 1993 & 47.091 & 67.075 & 145.136 & 323.233 & & 29.997 & 612.532 \\
\hline 1994 & 29.588 & 91.230 & 56.361 & 231.644 & 88.569 & 23.020 & 520.412 \\
\hline 1995 & 42.846 & 95.506 & 9.285 & 287.818 & 15.011 & 13.008 & 463.474 \\
\hline 1996 & 18.675 & 85.475 & 40.097 & 125.480 & 64.228 & 15.314 & 349.269 \\
\hline 1997 & & 54.333 & 10.898 & 30.670 & 63.631 & & 159.532 \\
\hline Total & 12.580 .571 & 1.438 .301 & 2.955 .538 & 15.199 .015 & 1.836 .503 & 117.934 & 34.127 .862 \\
\hline
\end{tabular}

Fonte: Elaboração do autor, com base em ICOMI (1997, p. 105).

Na década de 70, a tendência para a ampliação da oferta de manganês no mercado mundial é mantida, em decorrência do aparecimento de novas fontes de suprimento, da gradual expansão da produção da Austrália, do Gabão e do Brasil (Gráfico 8) e também da redução, como conseqüência da adoção de novas tecnologias siderúrgicas, do volume de minério de manganês requerido por tonelada de aço produzido - o que, segundo a ICOMI (1972, p. 26), "tornou o mercado de minério de manganês altamente competitivo". 
Essas mudanças no mercado mundial do manganês - fruto das oscilações ligadas à chamada escassez relativa do mineral - foram indutoras de mudanças na organização industrial adotada pela ICOMI para a valorização do manganês da Serra do Navio. De tal modo que a ICOMI introduziu a mais significativa das alterações nos processos de beneficiamento do manganês na história da empresa: a construção da usina destinada a concentrar as frações finas do minério de manganês na Serra do Navio e da usina de pelotização no Porto de Santana. Tais mudanças viabilizaram o aumento do volume de minério mercantilizado, que atingiu, em 1971, 1,6 milhão de toneladas - a marca mais expressiva na história da mina (Tabela 5). Tal aumento permitiu que, até 1976, houvesse uma ampliação do volume e da proporção do minério destinado ao abastecimento da indústria siderúrgica européia. A partir de 1978, assistiu-se à consolidação da tendência de redução crescente da proporção entre o minério extraído na mina e o destinado aos EUA. Naquele ano, tão-somente $16,5 \%$ das 783 milhões de toneladas comercializadas destinaram-se aos EUA (Gráfico 9).

Nos anos 80, a destinação de pequena parte do minério de manganês para aos EUA (Gráfico 9) sinalizava, claramente, a redução da importância da Serra do Navio para a Bethlehem Steel, uma dinâmica que culminou com sua saída do controle da ICOMI em 1988.

Assim, quando do encerramento da lavra na Serra do Navio, ainda existia uma elevada taxa de concentração nas áreas nas quais o minério era explorado, mas essa concentração era muito menor do que nos anos 50.

No final do século XX, a mercantilização do manganês estava dividida entre sete países, que respondiam por quase $80 \%$ da produção mundial. Em 2001, por exemplo, a África do Sul liderou a produção mundial, sendo responsável por 18,29\% desse volume, seguida pela Austrália com 10,34\%, pela China com 10,47\%, pelo Gabão com 11,35\% e finalmente pelo Brasil, que foi responsável por 8,69\% do minério de manganês mundialmente mercantilizado (DNPM, 2002).

\subsection{Processos produtivos requeridos pela valorização do manganês}

As minas da Serra do Navio, em sua ampla maioria, eram compostas de óxido de manganês e de uma pequena fração de protominério. O volume de minério nelas contido foi estimado em 66,702 milhões de toneladas (run of mine (ROM)). Desse volume, 61,133 milhões de toneladas de minério de manganês (ROM) foram lavrados, o que, segundo a ICOMI (1997, p. 72), representa 91,6\% do minério lá existente.

A valorização do minério de manganês da Serra do Navio, por conseguinte, requereu o acesso aos corpos mineralizados, a retirada do minério da crosta terrestre e seu beneficiamento. Como tais corpos encontram-se situados relativamente perto da superfície, a sua lavra era realizada a céu aberto (Figura 4). 


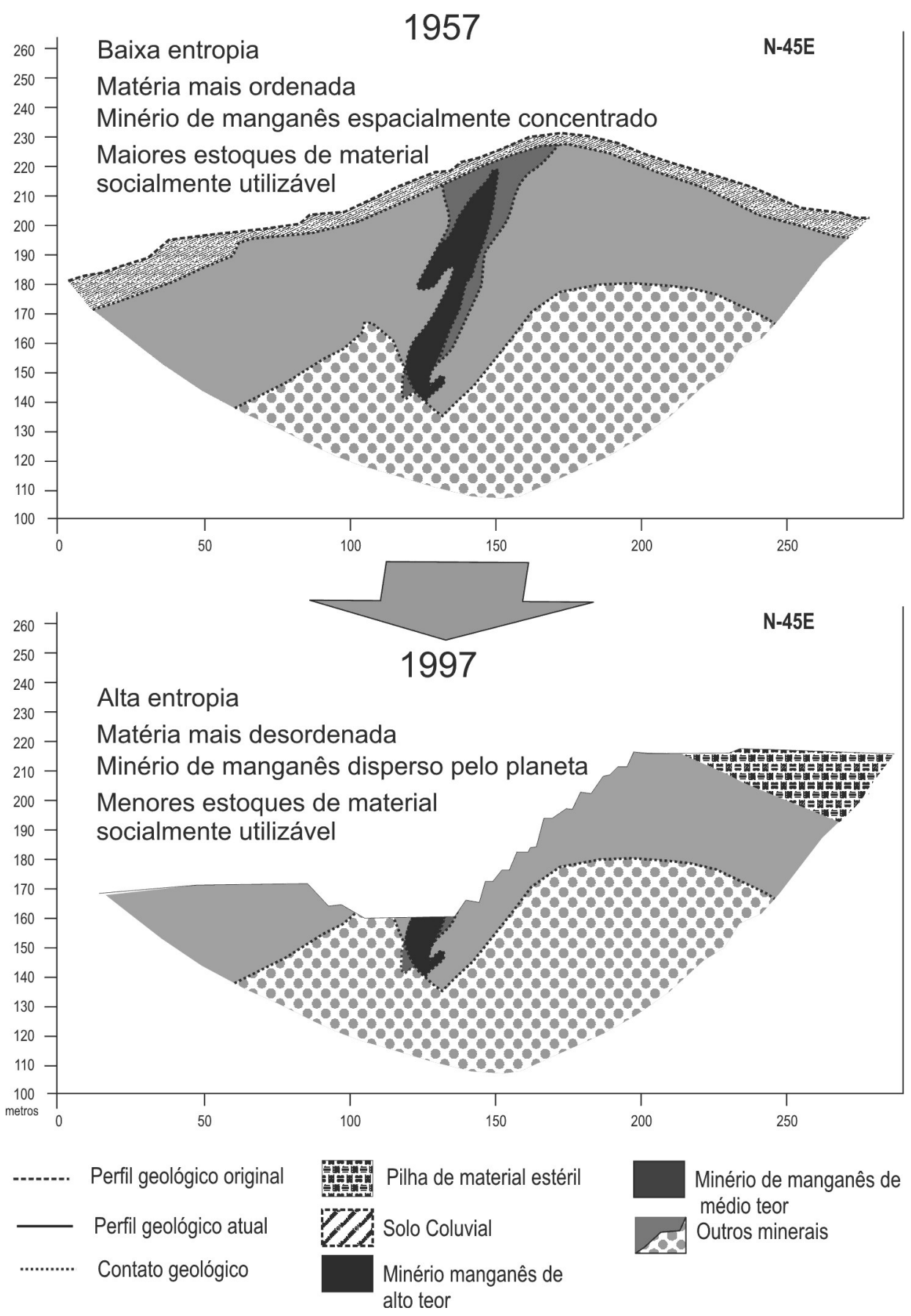

Figura 4: Representação esquemática de implicações entrópicas da valorização da mina de manganês T11, Serra do Navio, Amapá, Brasil.

Fonte: Elaboração do autor, com base em ICOMI (1997, p. 31). 
Na organização da lavra, a ICOMI dividiu os minérios em duas faixas: a de "alto teor", atribuída àqueles minérios cujo teor de manganês fosse superior a $42 \%$, e a de "baixo teor", que abarcava aqueles minérios cujo teor de manganês fosse inferior a esse patamar e se situasse entre 40\% e 32\% de manganês contido. Até os anos 70, para obter o teor médio desejado no minério a ser comercializado, limitava-se a realizar, durante o beneficiamento, um mix de classes de minérios com teores diferenciados (56\%, 52\%, 48\%, 44\%). Esse mix, em alguns casos, envolvia parte da classe de minério com teores de até $40 \%$ de manganês. O restante do minério considerado de baixo teor, que era retirado compulsoriamente para liberar o de "alto teor", era armazenado em pilhas na Serra do Navio.

A valorização implicava, primeiramente, o preparo da área por meio da retirada das camadas de material estéril e de protominério, permitindo o acesso ao corpo mineralizado e à extração do minério de manganês. Uma vez extraído, o minério era transportado para ser beneficiado. A remoção do capeamento estéril era realizada por equipamentos denominados motoscrapers. Em seguida, era realizado o desmonte, feito por tratores de esteiras. Quando os corpos mineralizados eram compostos por materiais maciços, para o desmonte, recorria-se inicialmente a explosivos (ICOMI, 1997, p. 79). Posteriormente ao desmonte, iniciava-se a retirada do minério por escavadeiras mecânicas, que também realizavam o seu carregamento em caminhões (Figura 4).

O minério era descarregado diretamente dos caminhões em um sistema de peneiras que fornecia ao britador primário somente o material acima de seis polegadas. Iniciava-se assim o beneficiamento do minério, que era realizado em uma usina de beneficiamento (GONÇALVES, 1976, p. 44). Como subprodutos do beneficiamento, havia o "miúdo" e o "fino" do minério, que possuíam granulometria inferior a $5 / 16$ polegadas, eram armazenados em pilhas separadas e não eram comercializados até os anos 70.

Durante o processo de beneficiamento, as impurezas contidas no minério bruto eram reduzidas, resultando em um produto cuja composição química enquadrava-se nos padrões indicados na Tabela 6.

Tabela 6: Composição média do minério de manganês metalúrgico comercializado pela ICOMI.

\begin{tabular}{ccc}
\hline Elemento & Percentual mínimo & Percentual máximo \\
\hline $\mathrm{Mn}$ & $49,5 \%(\mathrm{a})$ & $50,00 \%$ \\
$\mathrm{Fe}$ & $4,50 \%$ & $5,00 \%$ \\
$\mathrm{SiO} 2$ & $2,00 \%$ & $3,00 \%$ \\
$\mathrm{Al} 2 \mathrm{O} 3$ & $5,00 \%$ & $6,00 \%$ \\
\hline
\end{tabular}

De acordo com a ICOMI (1998, p. 4), o teor médio do produto comercializável oscilava em torno de 48,5\%, embora fossem feitas partidas com teores maiores.

Fonte: GONÇALVES (1976, p. 141). 
No final de 1971, tiveram início as obras visando à valorização do minério de manganês da mina F-12, situada à margem direita do rio Amapari (Figura 2). Para tanto, iniciou-se a construção de um britador e de uma correia transportadora sobre o rio Amapari, o que permitiria que a lavra e o beneficiamento do minério daquela mina começassem em maio de 1973 (ICOMI, 1997, p. 83).

Nesse cenário do início dos anos 70, no qual ocorreram mudanças no processo produtivo da ICOMI, houve também alterações na economia nacional. Nos primeiros anos da década de 70, a política dos governos militares para a Amazônia envolvia ações que visavam concentrar espacialmente os efeitos dos incentivos fiscais. Assim, a política de incentivos fiscais patrocinada pelo governo federal foi utilizada pela ICOMI para implantar uma usina de pelotização, que demandou na época US\$ 15 milhões, dos quais sete milhões foram oriundos de empréstimos externos e o restante, proporcionado pela utilização de incentivos fiscais (ICOMI, 1972, p. 21).

A partir da construção da usina, o tratamento do minério, que se restringia, até o início da década de 70 , basicamente à mixagem entre minérios de teores diferentes para atingir no mínimo 42\% de manganês metálico e sua padronização em relação à granulometria, passou a contar com usinas de concentração e de pelotização do manganês. A empresa começou então a aproveitar os finos de minérios de baixo teor de manganês, resultantes das operações de beneficiamento do minério na Serra do Navio. Do processo de pelotização, resultavam pelotas com teor aproximado de 55\% de manganês metálico (ICOMI, 1976, p. 17).

A empresa manifestava-se entusiasticamente em relação à usina, alardeava que ela tinha um caráter pioneiro e teria sido a primeira unidade de seu gênero a entrar em operação industrial no mundo, e que "os esforços conjugados da SUDAM e ICOMI para a construção desta usina pioneira valem como resposta a um verdadeiro desafio: a instalação de equipamentos de alta tecnologia em plena Amazônia, com todas as dificuldades que o funcionamento teria representado" (ICOMI, 1976, p. 17).

A usina entrou em operação em 1973 e, apesar de ter capacidade nominal para 250 mil toneladas por ano, a produção de pelotas atingiu no máximo 230 mil toneladas em 1978 (Gráfico 10).

Durante os anos 80, dada a paralisação das operações da usina de pelotização em 1985, a ICOMI introduziu diversas modificações para que a antiga usina produzisse sinter, convertendo-a de tal maneira em uma usina de sinterização. Essa usina entrou em operação em 1988 e passou a beneficiar os finos de minério de manganês gerados no beneficiamento na Serra do Navio. 


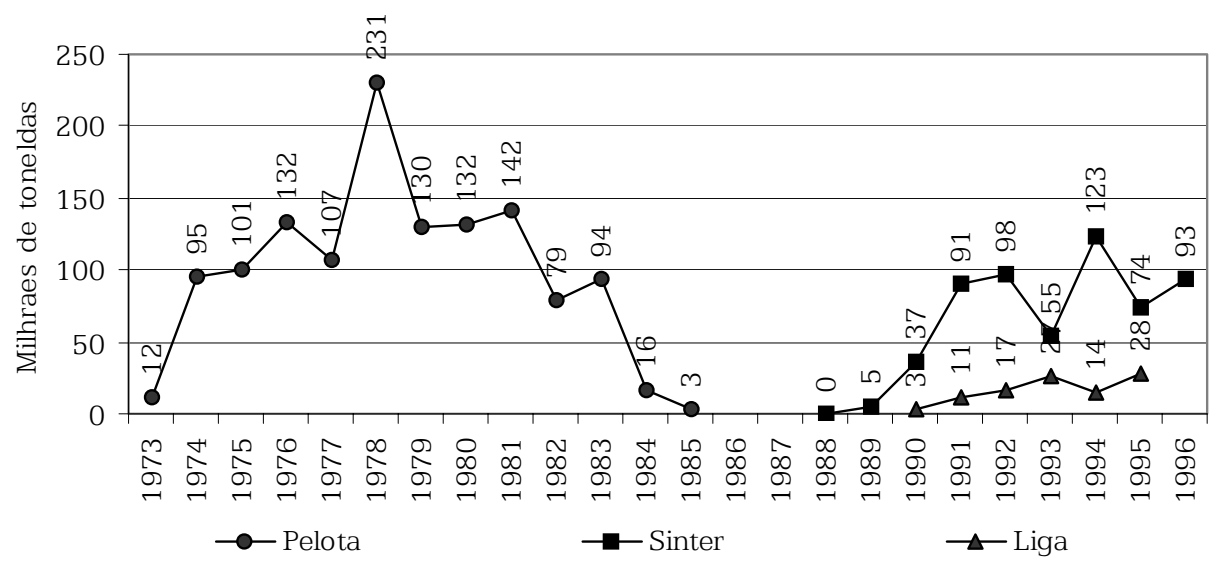

Gráfico 10: Volume de pelotas, sinter feed e ferro-ligas de manganês produzidos por empresas vinculadas à ICOMI.

Fonte: Elaboração do autor, com base em ICOMI (1997, p. 22).

Tais mudanças inseriram-se em um processo de reestruturação das atividades desenvolvidas no Amapá pela CAEMI, naquele momento controladora da ICOMI, que decidiu criar uma empresa - a Companhia Ferro-Ligas do Amapá (CFA) — que viesse a dedicar-se à explotação do minério de cromo (cromita) das minas de cromo na região do Vila Nova, à sua transformação metalúrgica e também à transformação metalúrgica do manganês, por meio da produção de ferro-ligas.

Assim, teve início, em 1989, a produção comercial do sinter de manganês. A mercadoria foi inteiramente exportada até 1990, quando entrou em operação a planta metalúrgica da CFA. A partir de então, parte do sinter de manganês produzido pela ICOMI teve como destino os fornos da CFA, onde era convertido em liga de ferro-manganês. Por conseguinte, as atividades metalúrgicas da CFA estiveram estreitamente relacionadas ao início da produção de sinter de manganês pela ICOMI. Portanto, quase concomitantemente à implantação da usina de sinterização pela ICOMI, a CFA implantou um forno elétrico para a redução de minérios de manganês e de minério de cromo dentro da área industrial da ICOMI, em Porto de Santana.

\section{ALGUMAS IMPLICAÇÕES AMBIENTAIS DA VALORIZAÇÃO DO MANGANÊS}

Como foi indicado, o processo de beneficiamento do minério de manganês na ICOMI sofreu mudanças significativas nos anos 70. Até esse período, o minério destinado ao beneficiamento era somente o considerado de "alto teor", e o principal produto da ICOMI, o chamado "Grosso 48", era obtido apenas com a britagem, a lavagem e o 
peneiramento do minério bruto na usina de beneficiamento. O minério bruto considerado de baixo teor era extraído compulsoriamente, ou seja, para liberar o de alto teor, era estocado em pilhas, em locais que permitissem o seu aproveitamento posterior. Essa destinação era dada igualmente aos subprodutos do beneficiamento do minério de alto teor, chamados de "fino" e "miúdo" (ICOMI, 1997, p. 4).

Em 1972, a empresa passou a utilizar novas unidades de beneficiamento que permitiram valorizar os chamados "finos" e "miúdos", subprodutos do beneficiamento do minério que possuíam teores médios de 44\% e 35\% de manganês. Por conterem um percentual de manganês situado abaixo do mínimo exigido pelo mercado, eram de difícil comercialização, sendo estocados na usina de beneficiamento na Serra do Navio. Para convertê-los em produtos com valor de uso, em 1972, foi construída junto da usina de beneficiamento na Serra do Navio uma usina de concentração de "miúdo" e "fino", cujo produto recebeu a denominação de pellet feed. Esse produto era, por sua vez, a matériaprima para a fabricação de pellets de manganês por meio da usina de pelotização, anteriormente citada, construída em Santana. Por meio das usinas de concentração e de pelotização, tornou-se possível o aproveitamento do "miúdo" e do "fino" gerados no beneficiamento do minério. Ao concentrá-los, elevando-se os teores de manganês e aglomerando-os, produzia-se uma mercadoria que atendia aos parâmetros de conteúdo metálico, de granulometria e de resistência física exigidos pelo mercado mundial (ICOMI, 1997, p. 4).

Por conseguinte, considerando as técnicas de beneficiamento usadas para valorizar o minério do manganês da Serra do Navio, é correto afirmar que a mineração na Serra do Navio teve duas etapas, cuja linha divisória é delimitada pela entrada em operação da usina de pelotização.

A usina de pelotização operou até janeiro de 1983. Segundo a empresa, a paralisação das atividades dessa usina deveu-se aos aumentos dos preços do óleo combustível. Ao aumento do combustível, conjugou-se a queda do mercado de pelotas, tanto em preço quanto em demanda (ICOMI, 1997, p. 6).

Com o encerramento das atividades da usina de pelotização, a ICOMI necessitava implementar outra alternativa que possibilitasse a valorização da parcela de minério cuja granulometria ficava abaixo das especificações preconizadas pela indústria siderúrgica. A ICOMI, então, começou a estudar alternativas para valorizar os "finos" gerados no beneficiamento do minério de manganês e optou pela edificação de uma planta industrial voltada para a aglomeração dos "finos" a partir da fabricação de sinter, que também seria utilizado como insumo na produção de ferro-ligas de manganês. Para tanto, foram introduzidas modificações na usina de pelotização desativada; a ICOMI passou, então, 
a contar, na área portuária do município de Santana, com uma usina de sinterização, com uma capacidade instalada de 140.000 t/ano de sinter.

Assim, a partir de 1988, a ICOMI passou a utilizar o processo de sinterização, por meio do qual aqueles "finos" de minério, que não teriam valor de uso, eram aglomerados, ganhando a possibilidade de valorização e conseqüentemente de mercantilização. A operação da usina de sinterização em 1989 permitiu à ICOMI, além de atender à demanda do mercado externo por sinter de manganês, tornar-se fornecedora dessa matéria-prima à Companhia Ferro-Ligas do Amapá (CFA), para a produção de ligas de ferro-manganês de alto carbono.

A produção de sinter iniciava-se com a preparação e a classificação granulométrica das matérias-primas, fundentes e carvão vegetal. Como em todo processo siderúrgico, a composição de carga em faixas bem delimitadas permite atingir maior eficiência. De tal forma, as matériasprimas antes enviadas ao forno são submetidas a um sistema de britagem e de classificação das faixas granulométricas. No caso da sinterização, o sistema requeria partículas com dimensões inferiores a seis milímetros (PLANASA, 1987, p. 21-22).

No processo de sinterização, os "finos" de minérios, fundentes e carvão vegetal eram previamente preparados e estocados em pilhas, de onde eram recolhidos para alimentar o forno da sinterização.

Os "finos" gerados correspondiam a cerca de 30\% do total processado (PLANASA, 1987, p. 24-25). Uma parcela desses "finos" era novamente inserida no forno, e a parte restante era destinada à bacia de rejeitos situada na própria área industrial, em Santana. Somente décadas depois, constatar-se-ia que essa forma de disposição dos rejeitos seria responsável pela contaminação por arsênio e manganês tanto de lençóis freáticos quanto de águas superficiais, como se indicará mais adiante.

\subsection{A tentativa de realizar a produção metalúrgica local}

A partir da parcela do sinter de manganês, cujo processo de produção foi anteriormente descrito, a CFA, subsidiária da ICOMI, passou a produzir ferro-ligas na própria área portuária em Santana. As ligas produzidas pela CFA eram classificadas, segundo o teor de carbono, em: ferro-manganês de alto carbono e ferro-silício-manganês de baixo teor de carbono (Tabela 7).

Em termos de aplicabilidade, as ligas de ferro-manganês de alto teor de carbono agem como desoxidantes, dessulfurantes e como introdutores de manganês no aço e no ferro fundidos de baixo teor em manganês. Já as ligas de ferro-manganês de baixo teor de carbono são usadas como agentes de adição para aço de muito baixo teor de carbono e em todas as ligas que exijam baixo teor desse elemento, inclusive as não ferrosas, que toleram certo teor de ferro (GONÇALVES, 1976, p. 4). 
Tabela 7: Especificações da composição das ligas que eram produzidas pela CFA.

\begin{tabular}{l|c|c}
\hline \multirow{2}{*}{ Elemento } & \multicolumn{2}{c}{ Composição em porcentagem } \\
\cline { 2 - 3 } & FeMnAc & FeSiMn \\
\hline Manqanês & $78-82 \%$ & $65-68 \%$ \\
Carbono (máx). & $7.50 \%$ & $2.00 \%$ \\
Silício (máx.) & $1.20 \%$ & $16-18.5 \%$ \\
Fósforo (máx.) & $0.35 \%$ & $0.20 \%$ \\
Enxofre (max.) & $0.05 \%$ & $0.04 \%$ \\
\hline
\end{tabular}

Fonte: PLANASA (1987, p. 30).

Para a produção de tais ligas, a CFA utilizava o processo de redução e fusão redutora. Esse processo é realizado por meio de um forno elétrico de redução. Nesse forno, a energia térmica é gerada pela passagem da corrente elétrica pela carga do forno. Essa corrente, de alta intensidade, era conduzida através de três eletrodos imersos na carga. Por esse motivo, o processo também é conhecido como "redução a arco submerso" (PLANASA, 1987, p. 25).

As matérias-primas escoavam de silos até o cadinho do forno, compondo dessa maneira o leito de fusão. Nesse cadinho, tinham início as reações de redução dos óxidos presentes na carga e também a fusão de todos os materiais, em razão das elevadas temperaturas obtidas pela passagem da corrente elétrica através da carga. À medida que os materiais carregados passavam para o estado líquido, escoavam para o fundo do cadinho do forno, aguardando o momento de vazamento. Uma vez completado o processo de redução e fusão, o forno era vazado, e o material líquido, constituído da liga e escória, fluía por gravidade para o sistema de lingotamento (PLANASA, 1987, p. 26).

A produção dessas ligas requer uma quantidade significativa de energia. Para a produção de uma tonelada de ferro-manganês de alto carbono, há consumo de energia elétrica da ordem de 2.600 kWh; para a produção de igual quantidade da liga de ferro-silício-manganês, são necessários, em média, $4.170 \mathrm{kWh}$. O forno elétrico da CFA e a usina de sinterização foram desativados em 1995 e 1996, respectivamente. Em ambos os casos, as plantas industriais foram desmontadas, e delas só restam no local as suas fundações.

A valorização do manganês, que envolveu sua extração, seu beneficiamento e a transformação primária de pequena parte do minério, requereu, assim, a movimentação e a dispersão de grande quantidade de matéria, a produção de significativo volume de rejeitos e a exaustão das diversas minas da Serra do Navio (Gráfico 11). 


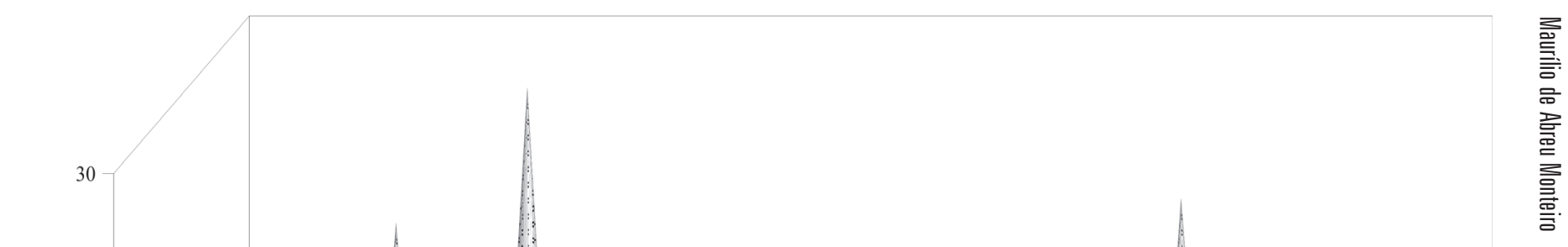

: Minério (mil t)

\begin{tabular}{|c|c|c|c|c|c|c|c|c|c|c|c|c|c|c|c|c|c|c|}
\hline T-11 & $\mathrm{T}-10$ & T-6 & $\mathrm{T}-4$ & $\mathrm{~T}-20$ & $\mathrm{~T}-8$ & A-12 & A-3 & C-10 & C-7 & C-3 & C-2 & C-1 & C-5 & F-12 & F-3 & V-1 & $\mathrm{V}-2$ & V-4 \\
\hline 1082 & 312,4 & 5426 & 2215 & 7494 & 490,2 & 3282 & 1424 & 3420 & 10,27 & 212,7 & 2146 & 69,53 & 704,2 & 5809 & 11,72 & 0 & 0 & 4,297 \\
\hline 833,8 & 240,7 & 4182 & 1707 & 5775 & 377,8 & 2529 & 1097 & 2635 & 7,912 & 163,9 & 1654 & 53,58 & 542,7 & 4477 & 9,03 & 0 & 0 & 3,311 \\
\hline 1939 & 559,8 & 9725 & 3969 & 13430 & 878,5 & 5881 & 2551 & 6129 & 18,4 & 381,2 & 3846 & 124,6 & 1262 & 10411 & 21 & 0 & 0 & 7,7 \\
\hline 3913 & 1130 & 19624 & 8009 & 27102 & 1773 & 11868 & 5148 & 12368 & 37,13 & 769,3 & 7762 & 251,4 & 2547 & 21008 & 42,38 & 0 & 0 & 15,54 \\
\hline
\end{tabular}

Estéril (mil t)

Gráfico 11: Material estéril movimentado, produção bruta e beneficiada em cada mina de manganês da Serra do Navio dissipada pela ICOMI.

Fonte: Elaboração do autor, com base em ICOMI (1997). 
Estima-se que, em 41 anos de operação, para a mercantilização de 33,2 milhões de toneladas de óxido de manganês e de 926 mil toneladas de carbonato, foi necessária a movimentação de mais de 123 milhões de toneladas de material estéril, o beneficiamento de mais de 61 milhões de toneladas de minério e a geração de mais de 26 milhões de toneladas de rejeitos (Gráfico 11).

O relatório da Comissão Parlamentar de Inquérito instalada na Assembléia Legislativa do Amapá indica que houve a produção de 52 milhões de produção mineral, em termos brutos (AMAPÁ, 1999).

Todavia, essa indicação pode induzir a equívocos, pois o que se comercializou efetivamente foi o minério submetido, após sair das minas (run of mine-ROM), ao beneficiamento primário (Gráfico 11) e sobre o qual incidiu realmente a cobrança de royalties. O minério comercializado totalizou 34,12 milhões toneladas (ICOMI, 1997, p. 105), valores que são confirmados pelo Anuário Estatístico do Amapá.

Os efeitos da movimentação desse material e da disposição dos rejeitos na área da Serra do Navio merecem ser mais bem investigados, em especial no que se refere à dispersão do manganês e de outras substâncias no meio físico, bem como à eventual constituição de via de exposição para populações humanas.

O processo de valorização das minas de manganês da Serra do Navio implicou conseqüentemente a dissipação daquelas minas. Entretanto, uma vez encerrado o processo de valorização do manganês, os equipamentos utilizados na lavra e no beneficiamento já não têm utilidade, as plantas industriais destinadas à transformação primária do minério foram desmontadas, restando em operação a Estrada de Ferro do Amapá e o terminal portuário. A rápida modernização industrial do então território federal do Amapá em decorrência da descoberta e da exploração das jazidas de manganês não se concretizou.

\subsection{Um passivo ambiental ainda a ser avaliado}

Em decorrência da valorização das minas de minério de manganês da Serra do Navio, além de sua dispersão, o encerramento da exploração industrial do manganês deixou como saldo um "passivo ambiental" ainda não avaliado em sua plenitude. Uma expressão desse passivo foi a detecção da contaminação de lençóis freáticos, na área do porto da ICOMI em Santana, como também de cursos d'água nas proximidades daquela área. Esse processo de degradação ambiental pode não estar limitado àquela área e ter ocorrido noutras onde a ICOMI atuou. 


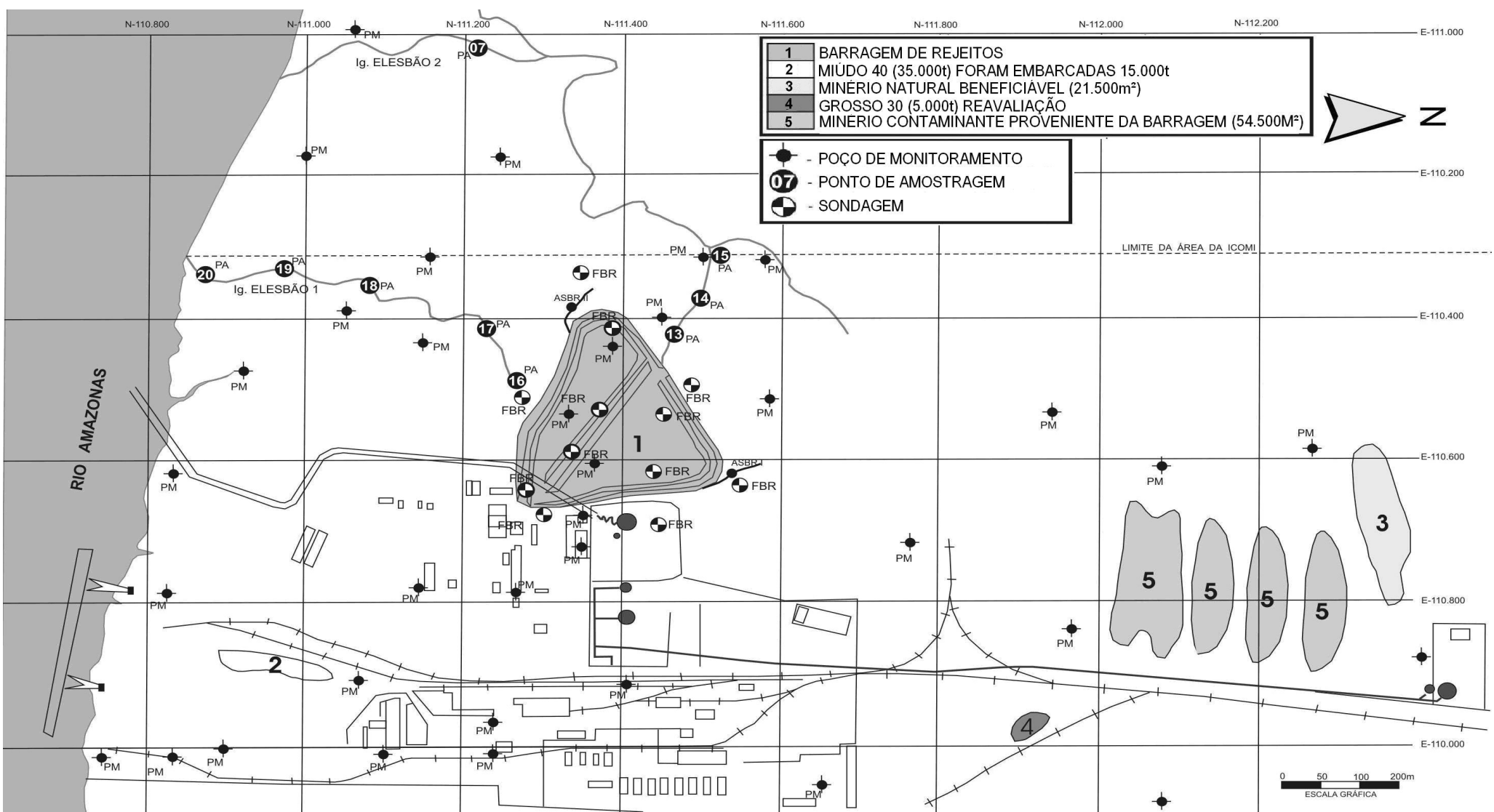

Figura 5: Indicação da fonte de contaminação por arsênio e localização das antigas instalações industriais e portuárias da ICOMI em Santana.

Fonte: Elaboração do autor com base em ICOMI (1997). 
Durante as negociações que envolviam a aquisição, pela Champion Papel e Celulose Ltda., da empresa AMCEL e do domínio útil da área industrial e portuária da ICOMI em Santana (Figura 5), foi solicitada pela Champion a realização de serviços de auditoria ambiental na área industrial e portuária. Foram então executados a avaliação ambiental, estudos de caracterização hidrogeológica e hidrogeoquímica de detalhe pela empresa Jaakko Pöyry Engenharia Ltda. (JPE).

A área estudada corresponde àquela que, ao longo dos anos, foi utilizada para a estocagem de minérios (manganês e cromo), produtos (pelotas, sinter e ligas) e insumos (combustíveis, coque, etc.), que entravam ou saíam pelo terminal portuário e ferroviário da ICOMI. Nas proximidades daquela área, em razão do crescimento populacional de Santana, surgiram diversas edificações que adensaram a ocupação urbana perto da área industrial. De tal forma que, atualmente, junto de uma parte dos limites da área da ICOMI, há moradias fixas, estabelecimentos comerciais e instalações portuárias.

$\mathrm{Na}$ auditoria realizada pela JPE, foi constatada a ocorrência de ferro (Fe), arsênio (As) e Manganês (Mn) em teores acima dos padrões estabelecidos pela legislação nas águas superficiais e subterrâneas. Dados os resultados, notadamente os dos teores de arsênio obtidos, e levando-se em consideração os efeitos e riscos potenciais à saúde causados especialmente pela contaminação por arsênio, decidiu-se por um detalhamento dos estudos nessa área no interior e nas vizinhanças da ICOMI (JPE, 1998, p. 24).

Constatou-se então que a presença de elevados níveis de arsênio está relacionada principalmente à disposição de resíduos de "finos" estocados na barragem de rejeitos e suas imediações e nos depósitos do mesmo material em suas vizinhanças. Segundo o estudo, a contaminação deve-se ao material residual dos processos de pelotização e de sinterização dispostos no local ao longo dos anos, até a paralisação da unidade no final de 1997 (JPE, 1998, p. 30).

Os rejeitos gerados nos processos de sinterização e de pelotização contendo arsênio e depositados na barragem atingiram as águas do nível freático e as águas superficiais dos pequenos igarapés Elesbão 1, Elesbão 2 (Figura 5). Os estudos da JPE comprovaram que os teores de arsênio decaíam com o aumento da distância em relação às bacias de disposição e que essa contaminação estava relacionada também aos efluentes da sinterização, desativada em 1996, como também à já citada barragem de rejeitos (JPE, 1998, p. 32).

Foi executado um monitoramento específico das águas, dos sedimentos e da ictiofauna por duas razões: em primeiro lugar, a população dos aglomerados populacionais, em especial de uma vila ribeirinha denominada Vila do Elesbão, construída em palafitas às margens do rio das Amazonas e estimada em 2.600 pessoas, poderia 
ter tido contato com as águas com elevados teores de arsênio; em segundo lugar, os sedimentos de fundo e da fauna aquática do igarapé Elesbão 2 poderiam estar comprometidos.

Os levantamentos realizados pela JPE concluíram que, mesmo com a paralisação da usina de sinterização e da conseqüente emissão de efluentes, tanto os teores de manganês quanto os de arsênio estavam acima dos limites. Além disso, constataram a existência de indícios de bioacumulação de ferro e de manganês em algumas espécies de peixes, embora não tenham detectado bioacumulação de arsênio nas amostras de peixe analisadas naquele estudo (JPE, 1998, p. 32).

Como ficou comprovado que os rejeitos contendo arsênio atingiram águas do nível freático e dos igarapés em decorrência da disposição inadequada dos rejeitos produzidos pelo processo de ustulação, tanto da pelotização quanto da sinterização do minério de manganês, a ICOMI foi multada em $\mathrm{R} \$ 52$ milhões. A empresa recorreu à justiça contra a multa, e ainda não existe decisão final do Judiciário.

Trabalhos de Pereira et al. (2001a), do Laboratório de Análises Químicas da Universidade Federal do Pará, apontaram a possibilidade de os rejeitos contendo arsênio também terem sido utilizados no capeamento de algumas ruas do município de Santana (Figura 1), o que configuraria outra provável via de exposição de populações humanas ao arsênio.

Naquele contexto a ICOMI passou a sugerir à Secretaria do Meio Ambiente, Ciência e Tecnologia do Estado do Amapá (SEMA) a implantação de um aterro no qual seriam dispostos os rejeitos contendo arsênio. Segundo a proposta inicial da empresa, esse aterro seria construído na área das minas Serra do Navio, possivelmente no local da cava resultante da lavra das minas "Terezinha 6", "Terezinha 20" ou "Terezinha 4", ou mesmo no local onde se localizava, na Serra do Navio, o antigo pátio de estocagem (Figura 2). A localização desse aterro na Serra do Navio implicaria a remoção do material contaminado da área portuária e industrial em Santana e sua transferência, por ferrovia, para a Serra do Navio.

Posteriormente, a ICOMI optou pela implantação de um aterro com o fundo e as laterais compactados e cobertos por uma manta impermeabilizante. Ele seria construído a 30 quilômetros do porto de Santana, às proximidades da estrada de ferro. Segundo a empresa, essa área, por suas características geológicas e hidrológicas, ofereceria melhores condições técnicas para a disposição final do rejeito. Todavia, a população que se localizava às proximidades não aceitou a instalação do aterro, chegando inclusive a atear fogo em parte da manta que impermeabilizaria o aterro.

Assim, foi inviabilizada essa alternativa para a disposição dos resíduos. Posteriormente, a empresa contratou uma empresa que transferiu o resíduo para um aterro industrial fora do Brasil. 
Estudos realizados por Pereira et al. (2001a, 2001b), com base em testes realizados em amostras de cabelo de moradores da área, indicaram que houve contaminação por arsênio em pessoas residentes na Vila do Elesbão. Por apontarem a exposição de populações residentes no entorno das instalações portuárias da ICOMI ao arsênio, tais estudos ensejaram a realização de novas avaliações. A Fundação Nacional de Saúde acionou o Instituto Evandro Chagas para realizar outras investigações acerca da exposição da população residente na Vila do Elesbão.

As conclusões desses estudos, posteriores aos de Pereira et al. (2001a, 2001b), apresentaram restrições ao estabelecimento de correlações entre a presença do arsênio e o desenvolvimento de doenças entre moradores da área. Assim, a presença de diversas patologias clínicas que afligem os moradores da área do entorno das áreas industriais da ICOMI em Santana não poderiam ser, segundo esses estudos (SANTOS et al., 2002), associados à contaminação por arsênio.

As análises físico-químicas das águas realizadas pelos pesquisadores do Instituto Evandro Chagas (LIMA et al., 2002) constataram a existência de teores de arsênio bastante elevados na área industrial da ICOMI. Isso causou a elevada presença de arsênio na água, nos sedimentos de fundo e no material particulado suspenso nos igarapés Elesbão 1 e Elesbão 2 em áreas mais próximas à barragem de rejeitos, como se verificou nos pontos de amostragem, como os de números 13 e 16 (Tabela 8).

Tabela 8: Resultados das análises de arsênio na água, nos sedimentos de fundo e no material particulado suspenso nos igarapés Elesbão 1 e 2.

\begin{tabular}{l|r|r|r|r}
\hline $\begin{array}{c}\text { Local da } \\
\text { amostragem }\end{array}$ & $\begin{array}{c}\text { Ponto de } \\
\text { amostragem }\end{array}$ & $\begin{array}{r}\text { Arsênio na } \\
\text { água (mg/L) }\end{array}$ & $\begin{array}{c}\text { Arsênio nos } \\
\text { sedimentos de } \\
\text { fundo (mg/g) }\end{array}$ & $\begin{array}{c}\text { Arsênio no material } \\
\text { particulado } \\
\text { suspenso (mg/g) }\end{array}$ \\
\hline Iq. Elesbão 1 & 16 & 4054,00 & 1591,50 & - \\
Iq. Elesbão 1 & 17 & 57,40 & 286,00 & 89,60 \\
Iq. Elesbão 1 & 18 & 16,00 & 87,70 & 45,80 \\
Iq. Elesbão 1 & 19 & 230,50 & 1030,80 & 695,90 \\
Iq. Elesbão 1 & 20 & 195,00 & 205,40 & 36,70 \\
Iq. Elesbão 2 & 6 & - & 7,90 & 30,00 \\
Iq. Elesbão 2 & 7 & 31,60 & 7,66 & 280,50 \\
Iq. Elesbão 2 & 13 & 114,20 & 239,80 & 207,00 \\
Iq. Elesbão 2 & 14 & 94,00 & & - \\
Iq. Elesbão 2 & 15 & 60,80 & 31,50 & 127,90 \\
\hline
\end{tabular}

Fonte: Elaboração do autor, com base em Lima et al. (2002).

Os estudos do Instituto Evandro Chagas indicaram também que a presença do arsênio tendia a reduzir-se à medida que se distanciava da barragem de rejeito (Gráfico 12). As pesquisas também apontaram:

a água do sistema de abastecimento (captação do rio Amazonas com e sem tratamento) apresentaram teores de arsênio menores 
que $0,5 \mu \mathrm{g} / \mathrm{L}$. Abaixo dos limites estabelecidos pela Portaria 1469 do Ministério da Saúde para águas de consumo, que é de 10,0 $\mu \mathrm{g} / \mathrm{L}$, e desta forma não poderiam ser consideradas como via de exposição (LIMA et al., 2002).

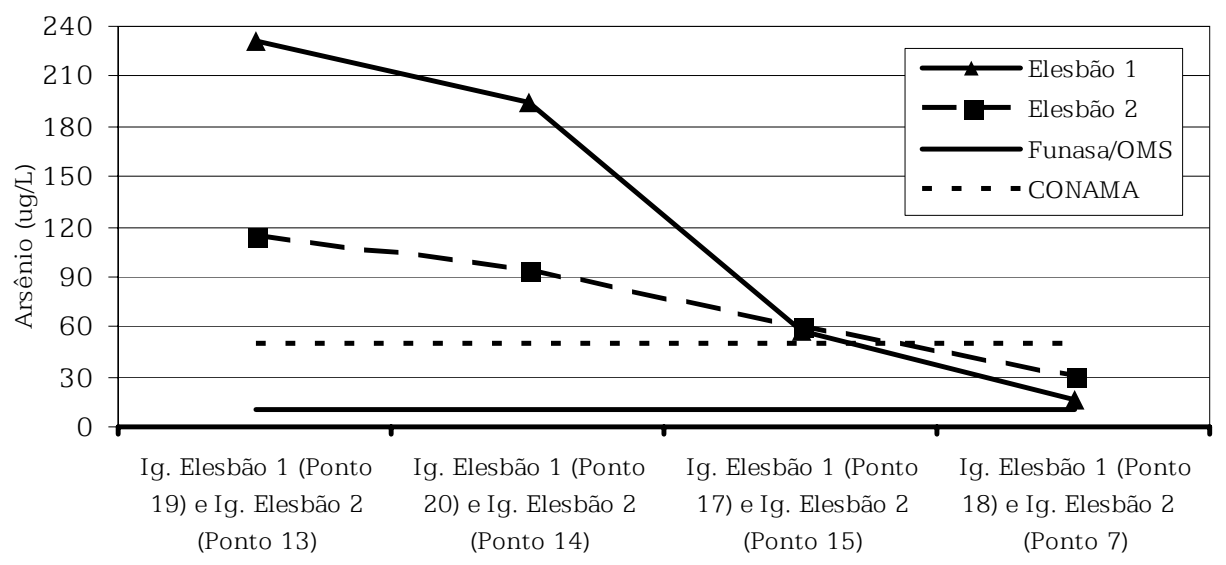

Gráfico 12: Resultados das análises de arsênio em águas superficiais nos igarapés Elesbão 1 e Elesbão 2.

Fonte: Elaboração do autor, com base em Lima et al. (2002).

No que se refere à avaliação da exposição de populações humanas ao arsênio e de suas implicações para a saúde, o Instituto Evandro Chagas também realizou estudos que envolveram 2.045 pessoas, das quais 881 homens $(43,1 \%)$ e 1.164 mulheres (56,9\%), com idades variando de 3 dias a 97 anos. Os estudos encontraram teores de arsênio no tecido capilar de 1.986 pessoas que variam de $0,06 \mathrm{mg} / \mathrm{g}$ a 5,85mg/ g, com média de 0,56 mg/g. As análises de sangue em 1.927 pessoas apresentaram média de 5,95 mg/L e uma variação entre 0,07 mg/L e 19,31 mg/L (SANTOS et al., 2002).

A avaliação médica realizada no âmbito dos estudos do Instituto Evandro Chagas constatou que o parasitismo na população alcançou 90,3\% dos 1.767 indivíduos pesquisados, dos quais 70\% estavam poliparasitados. A malária, por sua vez, atingiu $57,2 \%$ da população pesquisada. Além disso, a hepatite foi referida por 4,4\% dos entrevistados, e os casos de neoplasias atingiram 23\% das famílias (SANTOS et al., 2002).

Após cotejar os resultados das análises do material biológico (sangue e cabelo), indicadores de exposição, com os das patologias identificadas na Vila do Elesbão por meio da avaliação clínica, epidemiológica e laboratorial, os pesquisadores do Instituto Evandro Chagas concluíram:

[essas patologias] não apresentaram associação estatística significativa com as determinações de arsênio no sangue e tecido capilar da população estudada, estando em grande parte associada à precariedade das condições sanitárias, o que se reflete na qualidade de vida e saúde da comunidade (SANTOS et al., 2002). 
Contudo, há especialistas que - mesmo reconhecendo a seriedade do Instituto Evandro Chagas - alertam para o fato de as pesquisas desse instituto terem centrado o estudo apenas do arsênio, não abordando possíveis associações com a contaminação por manganês.

Além disso, a Pastoral da Criança, da Igreja católica, chamou a atenção para existência de casos de acefalia ou de microcefalia em crianças nascidas nas proximidades da mina da Serra do Navio, levantando também a hipótese de que tais casos poderiam ter relação com a contaminação por arsênio ou manganês, noutras áreas que não as situadas perto do igarapé Elesbão, em Santana.

Trata-se, portanto, de um passivo ambiental que necessita ainda ser mais bem avaliado. Trata-se também de um problema ambiental ainda sem solução, visto que os rejeitos, cujos teores médios de arsênio são de $1.877,7 \mathrm{mg} / \mathrm{g}(0,187 \%)$ (LIMA et al., 2002), ainda permanecem estocados em Santana e continuam sendo lixiviados para as drenagens do entorno da área industrial e portuária da ICOMI. Esse estudo necessita ser expandido para outras áreas onde houve a estocagem ou a disposição de minério de manganês, pois as análises das amostras de minério indicaram teores médios de arsênio de 1.496,9 mg/g (0,149\%).

\section{ALGUMAS CONTROVÉRSIAS ACERCA DO PAPEL DA ICOMI}

Argumentando que as reservas da Serra do Navio naquele contexto histórico ganharam enorme importância, Álvaro da Cunha (1962, p. 10) critica a "irreciprocidade das bases assentadas e [a] desigualdade dos compromissos assumidos" no contrato de arrendamento e o favorecimento de interesses privados em detrimento dos de caráter público. Ele censura também o interventor Nunes pela opção de transferir a exploração da jazida integralmente para o âmbito da iniciativa privada, em vez de constituir uma empresa sob controle estatal (CUNHA, 1962, p. 13). Segundo o autor, as bases foram de tal modo assimétricas que bloquearam a possibilidade de a exploração do manganês transfigurar economicamente o Amapá e integrá-lo à vida nacional (CUNHA, 1962, p. 10). Segundo ele, essa limitação deve-se, entre outras, às seguintes razões: uma empresa não estatal e de outra região não reinvestiria, regionalmente, seus lucros (CUNHA, 1962, p. 23); as alíquotas de royalties eram baixas (CUNHA, 1962, p. 103); os royalties incidiam, não sobre os lucros da empresa, mas sobre o seu faturamento (CUNHA, 1962, p. 59). O relatório final da Comissão Parlamentar de Inquérito da Assembléia Legislativa do Estado do Amapá (AMAPÁ, 1999), que se propôs a apurar a paralisação das atividades de extração mineral pela ICOMI, indica que a revisão contratual preparada pela empresa e aprovada pelo governo, em 1950, negou o que era 
fundamental no decreto que institui a jazida como uma "Reserva Nacional" (AMAPÁ, 1999, p. 16). Tal convicção justifica-se pelo fato de que, o arrendamento da jazida tendo sido fixado em 50 anos, a empresa deveria exportar no mínimo 500 mil toneladas ano. Além disso, o fornecimento para a indústria nacional deveria respeitar os contratos com terceiros:

[deixou-se de dar] importância ao manganês do Amapá para a indústria siderúrgica nacional, pois com um volume de exportação mínimo de 500 mil/ano [...] permitiu-se de antemão a lavra ambiciosa de um minério insubstituível, escasso e vital para a indústria siderúrgica (AMAPÁ, 1999, p. 16).

Leal (1988) e Cunha (1962, p. 53) também criticam o Estado nacional brasileiro por ter concedido uma série de favores, não exigidos contratualmente, à ICOMI, como a demarcação do canal norte da foz do rio Amazonas, pelo qual navegariam os navios com minério de manganês.

Em que pesem as críticas, é possível encontrar diversas e variadas manifestações extremamente otimistas, em especial em edições de jornais, nas quais a mineração e a atuação da ICOMI são apontadas como capazes de impulsionar rapidamente a modernização do Amapá.

Os efeitos da operação da empresa e os termos do arrendamento eram apontados no discurso oficial e de amplos setores da sociedade como fundamentais para o desenvolvimento do Amapá. Repetia-se à exaustão o discurso da própria empresa:

a descoberta do manganês e sua exploração anos depois vieram trazer um forte estímulo ao progresso do Território, tanto no que diz respeito à contribuição financeira, na forma de "royalties", impostos, salários, pagamentos e bens de consumo e serviços, como do ponto de vista social, pela maneira por que a concessionária da exploração das jazidas assiste a seus empregados e colabora com a comunidade amapaense (ICOMI, 1968, p. 2).

No que se refere à apresentação, em termos acadêmicos, de uma convicção otimista sobre as possibilidades de rápido desenvolvimento do Amapá, merece destaque o trabalho de Urech (1955). Ele apresentou uma visão muito favorável dos efeitos da mineração na economia do território. Preconizou que, a partir da mineração, abrir-se-iam as portas para o rápido desenvolvimento do território. Esse desenvolvimento resultaria da implantação de uma indústria siderúrgica que utilizaria, além do manganês, outros minérios existentes no território. Urech (1955) apresentava como grandes vantagens da possível produção siderúrgica no Amapá, além da presença local de minério, o acesso a 
fontes de energia de baixo custo, especialmente à biomassa originária da floresta primária, a partir da qual se poderia produzir carvão vegetal para abastecer altos-fornos produtores de ferro-gusa, como, aliás, já acontecia no Estado de Minas Gerais, ou ainda à energia elétrica oriunda da futura Usina Hidrelétrica Coaracy Nunes, que poderia alimentar a produção de ferro-ligas.

Villela e Almeida (1966, p. 180) também apresentam uma visão otimista do papel que a extração de manganês na Serra do Navio desempenharia na socioeconomia da região. Para eles, a capacidade gerencial, a utilização de técnicas modernas, o volume e a estabilidade da produção presentes na Serra do Navio indicavam a superação concreta do extrativismo tradicional e de práticas pré-capitalistas, o que permitiria impulsionar o desenvolvimento do Amapá. Os autores apontam a mineração na Serra do Navio como um dos poucos exemplos bem-sucedidos de empreendimentos capazes de modernizar a Amazônia, cuja economia tinha o crescimento bloqueado por diversos obstáculos de difícil transposição.

Um estudo realizado pelo Banco da Amazônia, em 1968, apresentou uma visão crítica da capacidade de a ICOMI impulsionar processos de desenvolvimento (BASA, 1969, p. 22). Tal estudo foi realizado pelo economista José Marcelino Monteiro da Costa, então chefe do Departamento de Estudos Econômicos do Banco. O escrito era fruto de uma colaboração do referido Banco com o Ministério do Interior que tinha por objetivo coletar informações para a elaboração de um diagnóstico urbano preliminar do Estado do Acre e dos territórios federais do Amapá, Roraima e Rondônia.

Ao referir-se à ICOMI, Costa argumentava:

a atividade econômica de maior destaque é o empreendimento que se ocupa da extração e exportação do minério do manganês, em virtude de sua fundamental importância no processo de geração da renda, no volume e valor das exportações e na oferta de empregos. Entretanto, é uma indústria caracteristicamente "encravada" na "economia tradicional" do Território. Os efeitos indiretos de arrasto (backward linkage) e de propulsão (forward linkage), propagados pela extração de minérios ao resto da economia amapaense, têm sido bastante débeis. Tal fato pode ser constatado pela queda vertiginosa da taxa de evolução da economia do Território quando excluída a atividade da mineração, não conseguindo sobrepor-se ao incremento demográfico (BASA, 1969, p. 22).

Para justificar sua posição, Costa argumenta que "os gastos que a ICOMI fazia se distribuíam aproximadamente da seguinte forma: 75\% no comércio da Guanabara, 15\% no de Belém e 9\% no de Macapá" (BASA, 1969, p. 22). 
Pinto (1977) também apresenta uma visão crítica da ICOMI, apesar de sua análise não se apoiar em pressupostos teóricos, como a de Costa (BASA, 1969). Afirma Pinto (1977, p. 96):

nos seus quase 20 anos de atividade, a ICOMI representou pouco para o país, muito menos do podem oferecer projetos de mineração desse tipo. Sem poder usar as reservas do Amapá, o país teve que aumentar progressivamente suas importações e, proporcionalmente, suas perdas nas relações de troca são substanciais.

Para ele, o ritmo da extração (considerado muito rápido) e a destinação do minério (destinado a atender somente interesses internacionais) eram contrários aos interesses nacionais, especialmente no que se refere ao fortalecimento da indústria siderúrgica brasileira (PINTO, 1977, p. 96).

No que tange à contribuição da empresa para o desenvolvimento do Amapá, Pinto (1977, p. 97) também não indica avanços, minimizando os efeitos do pagamento de royalties na socioeconomia do Estado:

Entre 1956 e 1966, a ICOMI conseguiu nas suas exportações 240 milhões de dólares e a maior parte dos royalties que pagaria ao governo do Território foram empregados para a construção de uma pequena hidrelétrica (que começa a funcionar no próximo ano com 40 mil kw e chegará no máximo a 80 mil kw), da qual a própria ICOMI será beneficiada.

Merece menção também, uma crítica, de fundamento estruturalista, acerca das possibilidades de a mineração impulsionar processos de desenvolvimento na Amazônia. Ela pode ser, grosso modo, considerada "uma versão energética e material" da teoria da dependência. É encontrada em Bunker (1985) que, ao analisar as repercussões de atividades responsáveis pela mercantilização de recursos naturais oriundos da Amazônia, argumenta que tais atividades organizam "economias extrativas" que diferem estruturalmente das "economias produtivas". As primeiras perdem, sistematicamente, em termos socioeconômicos; já as segundas ganham. Tal dinâmica vincularse-ia ao fato de que a degradação entrópica, inerente aos processos produtivos (GEORGESCU-ROEGEN, 1971), repercute negativamente nas economias das quais recursos materiais e energéticos são extraídos, enquanto nas que recebem esses recursos as repercussões são social e economicamente positivas. Para Bunker (1985), a degradação entrópica, como a resultante da exploração das minas da Serra do Navio (Figura 4), tem reflexos diferenciados nos processos de organização e de desenvolvimento das economias em termos planetários. O fluxo material em direção às "economias produtivas" reduz a complexidade e faz 
crescer a entropia nas "economias extrativas", enquanto aumenta a complexidade e o poder das outras. Seria, então, essa dinâmica estrutural que bloquearia o desenvolvimento de economias ligadas à exploração de minas como as da Serra do Navio.

Por fim, convém fazer referência ao trabalho de Brito (1995). Tratase, certamente, de uma análise que, em parte, foi influenciada pelas posições de Bunker (1985) e de Costa (BASA, 1969) - ambos tiveram uma grande atividade acadêmica no Instituto onde foi elaborado o escrito em questão. Provavelmente em decorrência de tais influências teóricas, Brito (1995, p. 132), apesar de dar ênfase às repercussões locais da atividade da ICOMI, de forma pendular, ora replica as teses estruturalistas vinculadas à "teoria da dependência", argumentando que a estrutura econômica do Amapá era dual e que o segmento tradicional não tinha como captar os impulsos decorrentes de segmentos modernos da economia, ora criticava a ICOMI, por não ser capaz de impulsionar o desenvolvimento do Estado.

\subsection{Limites teóricos das abordagens que investigaram o papel da ICOMI}

Ao dissipar matéria e energia, os processos produtivos geram rejeitos, reduzem a quantidade de energia disponível para realizar trabalho útil e os estoques de matéria socialmente aproveitáveis. Isso tem, evidentemente, repercussões sociais e econômicas na estruturação dos processos de desenvolvimento. No caso da ICOMI, nas áreas das minas na Serra do Navio, submetidas à exploração industrial e hoje exauridas, como na área portuária, passivos foram identificados.

Evidentemente, há passivos ambientais difíceis de serem detectados e mensurados, mas de implicações graves, como é o caso da constatação de que na área portuária os rejeitos contendo arsênio atingiram águas do nível freático e dos igarapés em decorrência da disposição inadequada dos rejeitos de atividades industriais. Como se indicou, trata-se de impacto decorrente da disposição inadequada dos rejeitos produzidos pela usina de pelotização de minério de manganês da ICOMI, implantada na década de 70. Entretanto, na época de sua instalação, a usina foi apresentada à sociedade local como fruto de "importantes pesquisas, desenvolvidas no Homer Research Laboratories, da Bethlehem Steel nos Estados Unidos" e indicada como um marco de um desafio vencido: "a instalação de equipamentos de alta tecnologia em plena Amazônia" (ICOMI, 1975, p. 17). Esse processo produtivo, apesar de ter sido apresentado à sociedade como portador de alta tecnologia, resultou em práticas ambientais prejudiciais.

Presentemente, alguns defensores do padrão de comportamento da ICOMI argumentam que avanços na tecnologia e na consciência 
ambiental só se efetivaram depois do início do processo e que aquelas práticas não poderiam, naquele momento, ser tomadas como agressões ao ambiente efetuadas por negligência ou dolo, pois não haviam sido social nem mesmo tecnologicamente estabelecidos parâmetros que as caracterizassem como tal.

A análise das práticas ambientais da empresa indica que a ICOMI, em sua trajetória, teve uma postura ineficaz em relação à biossegurança. Todavia, investigar as repercussões socioambientais da deposição dos rejeitos, da dispersão de materiais e do destino do minério extraído, como parte do esforço de apreender as interações entre a mineração industrial e o desenvolvimento, só faz sentido se essa investigação levar em conta que, assim como os fluxos monetários representam a aparência das relações subjacentes, os fluxos energéticos e materiais representam manifestações de superfície de uma vasta complexidade de interações entre lógicas distintas. Por isso, uma pesquisa sobre os efeitos da exploração mineral nos processos de desenvolvimento regional necessita identificar institucionalidades, estruturas, espacialidades, relações e determinações sociais que se configuram como o conteúdo essencial subjacente às formas manifestas, tanto nos fluxos monetários, quanto na degradação energética e material.

Em função dessas necessidades, também nos parece heuristicamente ineficaz fazer um balanço da relação entre a exaustão das minas de manganês da Serra do Navio e o desenvolvimento regional a partir de visões teóricas neoclássicas que partem do pressuposto de que, havendo a internalização das "externalidades negativas" decorrentes da exploração mineral, a mineração colaboraria para impulsionar processos de desenvolvimento tanto na região na qual ocorre a extração quanto naquela na qual há sua industrialização. Com efeito, na visão dos economistas de filiação neoclássica, a ampliação do comércio, como o decorrente da exploração das minas da Serra do Navio, beneficia todos os nele envolvidos, desde que as transações respeitem o "livre comércio" e as "vantagens comparativas na alocação dos fatores de produção". As formações econômicas e sociais tenderiam, portanto, a avançar para um equilíbrio em termos de desenvolvimento, quer se exportassem, quer se importassem bens de origem mineral, matériasprimas ou produtos elaborados. Uma agenda de pesquisa com base nesses supostos teria como foco os fluxos monetários e as eventuais falhas de mercado que, porventura, limitassem os benefícios decorrentes do livre comércio.

Já o problema central das abordagens inspiradas na termodinâmica clássica, como a de Bunker (1985), reside na incapacidade de incorporarem aos seus esquemas analíticos a noção de que a dissipação energético-material, vinculada à valorização de produtos naturais, pode 
não ter, necessariamente, um caráter socialmente negativo. Ou seja, a exploração e, por conseguinte, a dispersão do minério que está contido em uma mina podem contribuir ou não para que a região na qual se localiza a mina edifique instituições que favoreçam o desenvolvimento social.

É também limitado, analiticamente, elaborar uma interpretação das dinâmicas socioeconômicas impulsionadas pela exploração do manganês com base na visão da existência de uma economia dual (BRITO, 1995, p. 132) ou mesmo no conceito de enclave mineiro (CARDOSO; FALETTO, 1970, p. 48). Tais análises partem da convicção de que essas atividades formariam economias separadas das economias locais. Representariam assim um território separado de um domínio e contido em outro. As atividades desenvolvidas na exploração mineral seriam, portanto, núcleos de atividades primárias controladas de forma direta pelo exterior, ou uma jurisdição, ou uma economia (moderna) separada da economia local (atrasada) e compreendida em outra. Essa abordagem não dá a importância devida ao papel que a valorização de recursos minerais, mesmo tendo como finalidade atender a demandas extra-regionais, desempenhou, por diversas vias, na organização da socioeconomia do Amapá, na última metade do século XX. Mesmo que os efeitos de encadeamento para frente e para trás tenham sido muito reduzidos, como sugeriu Costa (BASA, 1969), não é eficaz analiticamente desprezar a ambiência social que viabilizou essa valorização e as alterações dela decorrentes.

\section{CONSIDERAÇÕES FINAIS: UMA AGENDA DE PESQUISAS EM ABERTO}

Parece evidente que as diversas interpretações analíticas do papel que a ICOMI desempenhou na estruturação da socioeconomia desta fração da Amazônia brasileira, na última metade do século XX, são insuficientes. Sobretudo, quando se leva em conta o encerramento de um período de meio século de atuação da empresa e o papel crescente que assume a extração e a transformação industrial de minerais na socioeconomia da Amazônia oriental brasileira. Há, por conseguinte, uma instigante agenda de pesquisas em aberto.

Fica evidente que é necessário compreender como as instituições bloquearam ou alargaram as possibilidades de impulsionar o enraizamento social do desenvolvimento, em regiões periféricas, a partir da valorização regional de produtos de origem mineral. Constata-se, de fato, entre outros aspectos, que, do valor adicionado pela atividade, apenas 12,69\% foram convertidos em salários e que tão-somente 10,72\% foram destinados a reinvestimentos na própria região. Houve, portanto, limitada capacidade de internalização do valor gerado pela mercantilização do minério de manganês. Os royalties pagos como 
compensação social pela mercantilização das jazidas de manganês da Serra do Navio foram os que tiveram as mais elevadas alíquotas em relação aos demais empreendimentos responsáveis pela valorização industrial de minérios na Amazônia brasileira.

Parece-nos, então, que a chave fundamental para se apreender as relações entre essa atividade e o desenvolvimento regional está na análise da organização institucional que foi edificada para viabilizar a mercantilização do minério de manganês no Amapá, das restrições de caráter sistêmico que influenciaram essas instituições, das limitações estruturais que as moldaram e das repercussões endógenas - efêmeras e duradouras - dos arranjos institucionais gestados. Por conseguinte, é forçoso compreender e explicitar em que medida tais arranjos institucionais bloquearam ou induziram o surgimento de trajetórias de enraizamento social do desenvolvimento na região.

\section{REFERÊNCIAS}

AMAPÁ. Assembléia Legislativa. Relatório final da Comissão Parlamentar de Inquérito da ICOMI. Macapá, 1999.

AMAPA. Anuário estatístico do Amapá. Amapá, 1968 e 1997.

BANCO DA AMAZÔNIA. Diagnóstico econômico preliminar das áreas urbanas do Acre, Roraima e Rondônia. Belém, 1969.

BUNKER, Stephen G. Underdeveloping the Amazon: Extraction, Unequal Exchange, and the Failure of the Modern State. Champaign: University of Illinois Press, 1985.

CARDOSO, Fernando Henrique; FALETTO, Enzo. Dependência e desenvolvimento na América Latina: ensaio de interpretação sociológica. Rio de Janeiro: Zahar, 1970.

CHANDLER, Alfred D. Ensaios para uma teoria histórica da grande empresa. Rio de Janeiro: Fundação Getúlio Vargas, 1998.

CUNHA, Álvaro da. Quem explorou quem no contrato de manganês do Amapá. Macapá: RUMO, 1962.

DEPARTAMENTO NACIONAL DE PRODUÇÃO MINERAL. Sumário mineral. Brasília, DF, 2002.

FERNANDES, Francisco Rego Chaves et al. Os maiores mineradores do Brasil: perfil empresarial do setor mineral brasileiro. São Paulo: EMEP; CNPQ, v. 3. p. 1012, 1982. 
GEORGESGU-ROEGEN, Nicholas. The entropy law and the economic process. 4. ed. Cambridge: Harvard University Press, 1971.

GONÇALVES, Everaldo; SERFATY, Abraham. Perfil analítico do manganês. Brasília, DF: DNPM, 1976.

GUERRA, Antonio Teixeira. Contribuição ao estudo da geologia do Território Federal do Amapá. In: GUERRA, Antonio Teixeira. Coletânea de textos geográficos. Rio de Janeiro: Bertrand Brasil, p. 271-311, 1994.

INDÚSTRIA E COMÉRCIO DE MINÉRIOS DE FERRO E MANGANÊS. O manganês no Amapá. Rio de Janeiro, 1958, 1968, 1975 e 1976.

INDÚSTRIA E COMÉRCIO DE MINÉRIOS DE FERRO E MANGANÊS. A exploração do minério de manganês do Amapá. Macapá, 1960.

INDÚSTRIA E COMÉRCIO DE MINÉRIOS DE FERRO E MANGANÊS. Usina de pelotização de Manganês. Macapá, 1972.

INDÚSTRIA E COMÉRCIO DE MINÉRIOS DE FERRO E MANGANÊS. Exaustão das reservas remanescentes do distrito manganesífero de Serra do Navio. Macapá: Roberto Costa Engenharia LTDA, nov. 1997.

JAAKKO PÖYRY ENGENHARIA LTDA. Anteprojeto de disposição final dos resíduos da usina de pelotização/sinterização estocados na área industrial da ICOMI - Santana - AP. Santana, AP, maio 1998.

LEAL, Aluízio Lins. Amazônia: aspectos políticos da questão mineral. 1988. 311 f. Dissertação (Mestrado em Planejamento do Desenvolvimento) - Núcleo de Altos Estudos Amazônicos, Universidade Federal do Pará, Belém, 1988.

LIMA, Marcelo O. et al. O estudo da dispersão do As no meio físico na área de estocagem de minério de $\mathrm{Mn}$ e adjacências no município de Santana, Estado do Amapá. Belém: Instituto Evandro Chagas, 2002. Relatório de pesquisa.

MORAES, Paulo Dias; MORAES, Jurandir Dias. O Amapá em perspectiva. Macapá: Valcan, 2000.

PAIVA, Glycon de; PARK JUNIOR, Charles F.; DORR II, John Van. Depósitos de manganês do distrito da Serra do Navio, território do Amapá. Rio de Janeiro: Departamento Nacional de Produção Mineral, 1950 (Boletim da Divisão de Fomento da Produção Mineral, 85).

PEREIRA, S. F. P. et al. Caracterização de arsênio em amostras de solo da cidade de Santana-Amapá. In: CONGRESSO BRASILEIRO DE QUÍMICA, 41., 2001, Porto Alegre. Anais... Porto Alegre, 2001a. 
PEREIRA, S. F. P et al.. Contaminação por arsênio em pessoas residentes às margens do rio Amazonas (vila do Elesbão - Santana - Amapá). In: ENCONTRO NACIONAL DE QUÍMICA ANALÍTICA, 11., 2001, Campinas, SP. Anais..., Campinas, SP, 2001b.

PINTO, Lúcio F.. Amazônia: o anteato da destruição. Belém: Grafisa, 1977.

PLANASA. Companhia de Ferroligas do Amapá - CFA. Projeto de implantação. Belém, 1987.

PLUNKERT, P. A.; JONES, T. S. Metal Prices in the United States through 1998. Washington, DC: Interior Dept., Geological Survey, 1999.

REIS, O. P. A crise do manganês amapaense: o dilema das economias produtoras exportadoras de matérias-primas. Belém: SUDAM, 1968.

RIBEIRO, Benjamin Adiron. Vila Serra do Navio: comunidade urbana na selva amazônica. São Paulo: Pini, 1992.

SANTOS, Elisabeth de Oliveira et al. Avaliação da exposição ao As associado ao rejeito de minério de Mn (mineração) no Estado do Amapá: abordagem da saúde humana. Belém: Instituto Evandro Chagas, 2002. Relatório de pesquisa.

URECH, Edouard. Esboço do plano de industrialização do Território Federal do Amapá: minérios e siderurgia. Rio de Janeiro: Di Giorgio, 1955.

VERGOLINO, José Luiz Ortiz. 50 anos de mineração industrial na Amazônia. 2002. Trabalho apresentado no Seminário 50 anos de Mineração Industrial na Amazônia, Macapá, AP, 12 a 15 de agosto de 2002.

VILLELA, Aníbal; ALMEIDA, José. Obstáculos ao desenvolvimento econômico da Amazônia. Revista Brasileira de Economia, v. 20, n. 2 e 3, p. 176-199, jun./set. 1966. 